\title{
Victims' Rights from a Restorative Perspective
}

\author{
Lara Bazelon* \& Bruce A. Green**
}

The criminal adjudicatory process is meant in part to help crime victims heal. But for some crime victims, the process is re-victimizing. For decades, efforts have been made to make the criminal process fairer and more humane for victims. For example, state and federal laws are now designed to keep victims informed, allow them to be heard at sentencing, and afford them monetary restitution. But these efforts, while important, have not persuaded crime victims to trust the criminal process. For example, sexual assaults remain grossly under-reported and underprosecuted. Less than 1 percent of sexual assault crimes result in a felony conviction. Even the few victims who do receive their promised retributive outcome are not necessarily healed by the process.

Reform efforts seem to presuppose that victims of crime-or victims of particular crimes such as sexual assaul - are essentially the same and have essentially the same need, namely, a need for the offender to be criminally prosecuted and sent to prison to serve the longest sentence the law allows. However, sexual assault victims are a diverse groupracially, ethnically, socio-economically, and with respect to sexual identity-and they suffer varied harms because sexual assault encompasses a wide realm of misconduct and victim-offender relationships or lack thereof. Even when victims suffer similar harms and come from similar backgrounds, they often have distinct, though sometimes overlapping, needs and objectives. Some have no desire to participate in the criminal adjudication process at all. Some will be retraumatized by a successful criminal prosecution, even with the implementation of procedural reforms promoted by the victims' rights movement and others.

Proceeding from the premise that victims are a diverse group with differing needs, we focus on victims who might prefer, and be better served by, a non-adversarial process that is centered on their needs, namely, restorative justice. However much improved, adversarial adjudication directed at convicting and incarcerating offenders risks re-traumatizing victims rather than promoting healing. It denies victims any significant control over the process, including control over their own narratives. We

\footnotetext{
* Lara Bazelon is a professor at the University of San Francisco School of Law where she holds the Phillip and Muriel Collins Barnett Chair in Trial Advocacy.

** Louis Stein Chair and Director of the Stein Center for Law and Ethics, Fordham University School of Law.
} 
explore the value of restorative justice processes as an alternative that, in many criminal cases, may be preferable from the victims' perspective. We acknowledge that restorative justice processes are rarely employed in sexual assault cases in the United States and that prosecutors may have reasons, independent of victims' perceived interests, for preferring the adversarial process, a criminal conviction and imprisonment. Further, some victims' advocates regard restorative justice as particularly inappropriate in the context of sexual assaults. Nonetheless, we suggest that when victims voluntarily choose to engage in a restorative justice process, it may be healing, because it gives victims agency in seeking a reckoning that fits with their particular needs and offers possibilities for addressing and repairing the harm that a criminal prosecution cannot.

\section{INTRODUCTION}

The victims' rights movement has made great strides to improve the adjudicatory process for crime victims in the United States: they are now entitled to notification of court proceedings, ${ }^{1}$ the right to seek monetary compensation from offenders, ${ }^{2}$ and the opportunity to make a victim impact statement, ${ }^{3}$ among other rights. But procedural reforms, including new ones inspired by the \#MeToo movement, ${ }^{4}$ cannot alter the fundamentally adversarial nature of our criminal justice system, which disempowers victims ${ }^{5}$ and has a significant potential to re-traumatize

1 See, e.g., ARIZ. REV. STAT. § 13-4406 (2019) ("On becoming aware of the date, time and place of the initial appearance of the accused, the law enforcement agency shall inform the victim of that information unless the accused appeared in response to a summons or writ of habeas corpus. In that case, the prosecutor's office shall, on receiving that information, provide the notice to the victim."); see also ARIZ. REV. STAT. § 13-4409(A)(2019) ("Except as provided in subsection B, the court shall provide notice of criminal proceedings, for criminal offenses filed by information, complaint or indictment, except initial appearances and arraignments, to the prosecutor's office at least five days before a scheduled proceeding to allow the prosecutor's office to provide notice to the victim.").

2 The federal Victim and Witness Protection Act, for example, provides that the court may order restitution for the "cost of necessary medical and related professional services... [and] for income lost.” 18 U.S.C. $§ 3663$ (2008). Note, however, that courts have interpreted this statute as excluding restitution for "mental anguish and suffering." United States v. Husky, 924 F.2d 223, 22627 (11th Cir. 1991).

3 In Payne v. Tennessee, 501 U.S. 808 (1991), the United States Supreme Court ruled that the Eighth Amendment allows the prosecution to introduce a victim impact statement at the sentencing phase of a capital case because it is "relevant evidence" to the determination whether impose the death penalty. See generally Robert C. Davis \& Carrie Mulford, Victims' Rights and New Remedies: Finally Getting Victims Their Due, 24 J. CONTEMP. CRIM. Just. 198 (2008).

4 Alta Viscomi, System Accountability and Sexual Violence: The Past and Future of the Criminal Justice System, 22 RichMOND PuB. INT. L. REV. 173, 181-88 (2019) (noting "the often-brutal [nature of the] court confrontation process" continues in the post \#MeToo era as do the barriers victims, particularly women of color, face in providing their cases).

5 Linda G. Mills, The Justice of Recovery: How the State Can Heal the Violence of Crime, 57 HASTINGS L.J. 457, 461 (2006) ("Critics of the victims' rights movement, however, question the 
them at precisely the time when the state should be helping them heal. ${ }^{6}$ Crimes involving sexual assault have a particular potential to re-harm victims because the adjudicatory process keeps its focus squarely on the offender and subordinates the interests of all other actors to achieving a conviction and retributive outcome. Most sexual assaults are never reported. ${ }^{7}$ If a criminal case is initiated, control over the victim's narrative as well as every major decision about the case is ceded to the state. ${ }^{8}$ The vast majority of cases end in plea bargains, ${ }^{9}$ which may leave victims dissatisfied because they never had a chance to tell their story and because the bargain itself may seem unfair or unrepresentative of what happened to them. ${ }^{10}$ In the rare case where there is a trial, the victim's narrative is shaped by the prosecutor, the victim must undergo cross-examination by the defense attorney, and the matter of punishment is up to the judge. ${ }^{11}$

Our inquiry focuses on the harms that victims experience during criminal adjudication through trial and sentencing. Victims' reform efforts tend to "essentialize" crime victims, that is, to regard them as if they are essentially the same and have essentially the same needs and objectives. ${ }^{12}$ But crime victims - and even victims of particular crimes - are not a monolithic group. ${ }^{13}$ Sexual assault victims, in particular, are diverse across racial, ethnic, socio-economic lines; some are

substance of [rape law reforms], noting that victim participation in criminal trials is largely symbolic. Moreover, courtroom dynamics subscribe a passive role to victims, who perform only when the prosecutor and the law invite such participation.").

6 See generally Susan Herman, Parallel Justice for Victims of Crime (2010).

7 Amy Kasparian, Justice Beyond Bars: Exploring the Restorative Justice Alternative for Victims of Rape and Sexual Assault, 37 SuffolK TrANSNAT'L L. REV. 377, 388-89 (2014) (stating that "[t]he reforms of the past forty years" are little more than "symbolic steps" and that most rape and sexual assault remain unreported and unprosecuted); Viscomi, supra note 4, at 181 (citing statistics).

8 See Mills, supra note 5, at 458-62.

9 Innocence Staff, Guilty Pleas on the Rise, Criminal Trials on the Decline, INNOCENCE Project (Aug. 7, 2018), https://www.innocenceproject.org/guilty-pleas-on-the-rise-criminal-trials-onthe-decline/ ("Over the last 50 years, defendants chose trial in less than three percent of state and federal criminal cases - compared to 30 years ago when 20 percent of those arrested chose trial. The remaining 97 percent of cases were resolved through plea deals."); See also Jon Stinchcomb, Most Sexual Assault Cases Don't Go to Trial. Here's Why., Port Clinton News Herald (Aug. 24, 2018), https://www.portclintonnewsherald.com/ story/news/local/2018/08/24/ohio-sexual-assault-cases-trialsentencing-plea-deal/978088002/.

10 Danielle Sered, Until We Reckon 32-33 (2019) (explaining why a plea to a lesser charge "can feel profoundly disrespectful of [the victim's] experience").

11 Mills, supra note 5, at 460-61.

12 Aya Gruber defines "essentialism” as "the practice of treating certain 'groups,' whether racial, gender, socio-economic, or ethnic, as though they all share the same beliefs, traits, goals, and desires." Aya Gruber, The Feminist War on Crime, 92 IowA L. REv. 741, 774-75 (2007). Essentialism, Gruber writes, also operates from a reductionist view of the offender: "Defendants are subhuman; they are monsters." Id. at 775.

13 See Kathryn Casteel, Julia Wolfe \& Mai Nguyen, What We Know About Victims of Sexual Assault in America, FiveThiRTYEight (Sept. 21, 2018), https://projects. fivethirtyeight.com/sexualassault-victims/. 
members of LGBTQ groups, some are men. ${ }^{14}$ The sexual violence they experience includes a wide array of crimes - misdemeanors and felonies, stranger attacks and assaults by people they know. Even victims who experience similar harms and come from similar backgrounds may have a multiplicity of needs that go unmet even under the "best case scenario" where there is a conviction and severe sentence. We explore how the criminal process can serve the victims who want no part of the adversarial process, not by promising to reduce the traumatic nature of criminal prosecutions to a tolerable level — which is not always possible — but by acknowledging that for some victims, there may be a different and preferable path. Empirical data suggests that for many survivors, the road to recovery involves "regaining power and control over what occurs in the aftermath of an assault, including the ability to make choices about when, how, and with whom to share their story, and the ability to limit their exposure to situations that may cause flashbacks or retraumatization." 15

The criminal justice system, by design, is not set up to provide this kind of choice and empowerment. As the criminologist Lisa Frohmann has noted:

$[u]$ nder current legal practice, the victim's affective and personal concerns are secondary to the concerns of the organization. To elevate the priority of victim's concerns, to have them play a more active ... role in the processing of sexual assault complaints, major structural and ideological changes in the legal system would have to occur. ${ }^{16}$

Yet the adjudicative process cannot accommodate such changes, which would radically undermine basic constitutional guarantees, including the right of the

14 Victims seared into the public consciousness include Trish Meili, in the infamous 1989 Central Park Jogger case, and Catherine "Kitty" Genovese, who was sexually assaulted and ultimately killed on a street near her home in 1964. Both victims were white, attractive, and middle class. Their attackers were men of color with violent criminal histories who they did not know. In Meili's case, the prosecution charged and wrongfully convicted five black and Hispanic teenagers. Years later, Matias Reyes, who is Puerto Rican, and had raped numerous other women in stranger attacks, confessed to the crime. Alfred Joyner, Who is Matias Reyes? Serial Rapist and Murderer in the Central Park Five Series When They See Us, NEwsweEK (June 4, 2019), https://www.newsweek.com/who-matias-reyesserial-rapist-murderer-central-park-five-series-when-they-see-us-1442045. His DNA matched the DNA from the crime scene. Jim Dwyer, The True Story of how a City in Fear Brutalized the Central Park Five, N.Y. Times (May 30, 2019), https://www.nytimes.com/2019/05/30/arts/television/whenthey-see-us-real-story.html. A black man named Winston Moseley was arrested and convicted for the sexual assault and murder of Genovese. Some experts believe that his confession was coerced. Saul Kassin, The Killing of Kitty Genovese: What Else Does this Case Tell Us?, 12 PERSP. On Psychol. SCI. 374 (2017).

15 Stefanie Mundhenk Harrelson, I Was Sexually Assaulted. And I Believe Incarcerating Rapists Doesn't Help Victims Like Me, THE APPEAL (July 18, 2019), https://theappeal.org/i-was-sexuallyassaulted-and-i-believe-incarcerating-rapists-doesnt-help-victims-like-me/ (citing Judith Lewis Herman, Justice from the Victim's Perspective, 11 Violence AgAinst Women 571 (2005)).

16 Lisa Frohmann, Constituting Power in Sexual Assault Cases: Prosecutorial Strategies for Victim Management, 45 Soc. Probs. 393, 404 (1998). 
accused to present a defense and to confront and cross-examine witnesses. ${ }^{17}$ Empowering victims would also be contrary to the traditional understanding of prosecutors' role and responsibility to seek justice, which requires declining to prosecute cases that cannot be proven beyond a reasonable doubt and determining whether the public interest demands a result different from what the victim desires. ${ }^{18}$

In part, our inquiry offers a frank assessment of the limitations of criminal procedure in the United States viewed from crime victims' perspective. By its nature, the adversary process denies victims autonomy and puts them at risk of further psychological harm and invasion of privacy. While procedural reforms may enhance victims' participation or reduce the intrusiveness of direct and crossexamination, many victims will continue to find the process inhospitable, if not painful. We also critique the victims' rights efforts insofar as they fail to acknowledge important differences among crime victims. This movement overlooks those who seek to avoid the criminal process because they will not be healed, but expect only to be further harmed, by a criminal prosecution, even one that results in the offender's conviction and incarceration. We then explore whether there are other ways to advocate for victims, specifically victims of sexual assault, outside of the traditional criminal justice system, that may provide better opportunities to exert agency and promote healing. We focus on one of these alternatives, restorative justice, and discuss how it might apply in sexual assault cases. ${ }^{19}$ Notably, while other countries have used restorative justice in cases involving violent crimes, there is little data on its effectiveness with respect to sexual

17 U.S. Const. amend. VI; see, e.g., Crawford v. Washington, 541 U.S. 36, 62-63 (2004) ("Dispensing with confrontation because testimony is obviously reliable is akin to dispensing with jury trial because a defendant is obviously guilty. This is not what the Sixth Amendment prescribes."); Davis v. Alaska, 415 U.S. 308, 320 (1974) ("The State's policy interest in protecting the confidentiality of a juvenile offender's record cannot require yielding of so vital a constitutional right as the effective cross-examination for bias of an adverse witness.").

18 See Bruce A. Green, Why Should Prosecutors “Seek Justice”?, 26 FORDHAM URB. L. J. 607 (1999); Bruce A. Green \& Rebecca Roiphe, A Fiduciary Theory of Prosecution, 69 AM. U. L. REV. 101 (2020); see also StANDARDS FOR CRiminal Justice 3-1.2(c) (AM. BAR Ass'N 1993); Model Rules of PROF'L CONDUCT r. $3.8 \mathrm{cmt}$. (AM. BAR ASs'N 2008) (The "seek justice" imperative is referred to as a "higher duty," which requires the prosecutor to serve as "a minister of justice and not simply ... an advocate"). While this requirement is somewhat vague, it does "tell[] prosecutors that their role includes more than seeking conviction at all costs." Fred C. Zacharias, Specificity in Professional Responsibility Codes: Theory, Practice, and the Paradigm of Prosecutorial Ethics, 69 Notre Dame L. Rev. 223, 259 (1993); see also Susan Bandes, Loyalty to One's Convictions: The Prosecutor and Tunnel Vision, 49 HowARD L. J. 475, 483 (2006) ("The duty to act as a zealous advocate and the duty to act as a minister of justice are not contiguous; some tension between them seems inevitable."); Paul H. Robinson, Should the Victims' Rights Movement Have Influence Over Criminal Law Formulation and Adjudication?, 33 MCGEORGE L. REV. 749 (2002) (tying case outcomes to an objective measure of blameworthiness not an individual victim's need for retribution or lack thereof).

19 We make this inquiry mindful of its controversial nature. Those who advocate for restorative justice in sexual assault cases, including survivors, have been subjected to public condemnation and ridicule. See, e.g., Harrelson, supra note 15, at 2 (writing that "talking about restorative justice as a solution to rape instead of incarceration has resulted in me being called 'stupid,' 'naive,' 'malevolent,' and a 'bitch"'). 
assault crimes in particular. ${ }^{20}$ Within the United States, restorative justice is rarely employed in cases involving violent crime and almost never in sexual assault cases, ${ }^{21}$ making data hard to come by. ${ }^{22}$ For this reason, our discussion of restorative justice and sexual assault is necessarily preliminary - a further step in what we hope will be an ongoing and increasingly data-backed, as well as story-driven, exploration.

This article contributes to a collection of articles responding to the effects of the \#MeToo Movement on criminal law and procedure. It seeks to add not only to the literature on victims' rights and the role of restorative justice in the criminal process in general, but also to the literature on how sexual offense victims should be treated in the criminal process. This question takes on added significance given the \#MeToo Movement's success in broadening public understanding of the harms caused by sex offenses and in encouraging more rigorous prosecution of sex offenders, ${ }^{23}$ to which some states have responded by reforming their laws to create new crimes, increase penalties, and extend statutes of limitations to bring suit and

20 Countries including Australia, Canada, and the United Kingdom have used restorative justice practices in response to violent crime with positive results: a lower rate of recidivism and higher rate of satisfaction from the victims. See Heather Strang \& Lawrence W. Sherman, Repairing the Harm: Victims and Restorative Justice, 2003 UTAH L. REV. 15 (2002) (discussing a decade of "research and development work on restorative justice in the common law jurisprudence of Australia and England" and reporting that victims stated they got "more "justice" from the restorative process than the traditional legal system); Mark S. Umbreit et al., The Impact if Victim-Offender Mediation: Two Decades of Research, 65 FED. Probs. 29 (2001) (reporting the same over two decades). Currently, there are only a few projects scattered across the United States that apply restorative justice practices in cases of serious violent crime (excluding sexual violence), but these have shown promising results. See, e.g., Danielle Sered, A New Approach to Victim Services: The Common Justice Demonstration Project, 24 FED. SENT'G REP. 50 (2011) (describing a restorative justice program that diverts violent offenders in New York). Vermont has a statute making it a "state policy" to "develop and employ restorative justice approaches whenever feasible and responsive to specific criminal acts." VT. STAT. ANN. tit. $28 \S 2$ (a) (2012). But the law carves out an exception for sexual assault related crimes. VT. STAT. ANN. tit. 24, § 1967 (2008). In 2018, however, "Vermont created a restorative justice study committee" to re-examine whether restorative justice might be used in sexual assault cases. Cara Kelly \& Aaron Hegarty, \#MeToo Was a Culture Shock. But Changing Laws Will Take More Than a Year., USA TODAY (Oct. 5, 2018), https://www.usatoday.com/story/news/investigations/2018/10/04/metoome-too-sexual-assault-survivors-rights-bill/1074976002/.

21 One exception is RESTORE, a federally funded pilot program in Pima County, Arizona that operated from 2004-2007. In all, 22 misdemeanor and felony sexual assault cases were referred by prosecutors to the program. Repeat sexual offenders were excluded as were those accused of domestic violence. Mary P. Koss, The RESTORE Program of Restorative Justice for Sex Crimes: Vision, Process, and Outcomes, 29 J. INTERPERSONAL VIOLENCE 10-12 (2013), https://publichealth. arizona.edu/sites/publichealth.arizona.edu/files/14\%2004\%2024\%20RESTORE\%20On-

line\%20published.pdf [hereinafter Koss, The RESTORE Program]. Koss's peer-reviewed published report analyzing RESTORE's data found that two-thirds of felony-referred defendants and 91 percent of misdemeanor-referred defendants successfully completed the program and that 90 percent of all participants believed that "justice was done." Id. at 32 .

22 Id. at 3 (stating that "[s]cholarly discourse on RJ for sexual assault has been hindered by lack of empirical data and is predominantly conceptual and dialectic.").

23 See, e.g., Lesley Wexler et al., \#MeToo, Time's Up, and Theories of Justice, 2019 Ill. L. Rev. 45, 49-68 (2019). 
file charges. ${ }^{24}$ Like earlier reform efforts designed to help crime victims, the \#MeToo Movement focuses predominantly on punishing offenders: it envisions criminal trials as a forum in which women who are victims of sexual offenses can regain their voices and where guilty verdicts will serve as affirmations of victims' experiences, facilitating healing. ${ }^{25}$ Our objective is not to deny the restorative power of successful prosecutions for some victims, but to question whether criminal prosecutions best serve victims in all cases, and to contrast criminal adjudication with processes that are more explicitly designed to be restorative for victims. Ultimately, we seek to expand the national discourse by encouraging thoughtful consideration of reparative alternatives, such as restorative justice processes, that are not solely concerned with punishment but rather emphasize accountability and healing.

\section{BACKGROUND: THE DEVELOPMENT OF VICTIMS’ RIGHTS LAWS}

\section{A. Early Efforts to Reform the Adjudicatory Process to Benefit Crime Victims}

In the United States, organized efforts have been made for more than a century to improve the criminal justice process from victims' perspective. ${ }^{26}$ Some of the efforts have focused on victims of particular crimes, such as sexual assault or domestic violence, and others have focused on crime victims as a class. Some of the focus is on improving social services and other assistance to crime victims. But much of the focus, and the subject of our discussion, concerns ameliorating the harms to victims caused not so much by the crime but by the ensuing criminal adjudicative process.

Like the current \#MeToo Movement, some early reform efforts specifically targeted how the criminal laws and processes unfairly treated women who are victims of sexual assault. Until the 1970s, many states did not recognize spousal rape, required that victims prove they physically resisted, were unlikely to prosecute date rape, and allowed cross examinations so broad as to place the victim's unrelated

24 See Holly R. Lake, \#MeToo Movement's Law and Policy Impact on Hollywood, 42 L.A. Law (2019); Corina Knoll, 'I Can Still Smell Him': For 4 Legislators the Child Victims Act is Personal, N.Y. Times (Aug. 19, 2019), https://www.nytimes.com/2019/08/19/nyregion/child-victims-actlawmakers.html; Sami Sparber, Texas Toughens Penalties For Groping, Hous. CHron. (June 14, 2019), https://www.houstonchronicle.com/news/politics/texas/article/Texas-toughens-penalties-for-groping13999189.php.

25 Two notable responses to this movement were the prosecution of Larry Nassar, in which more than 100 victims testified at his sentencing following his guilty plea, and the New York prosecution of Jeffrey Epstein, at which the judge allowed putative victims to give similar testimony following Epstein's death in prison before a trial could commence. Both victim impact proceedings were controversial - the Epstein proceeding especially so. See Bruce A. Green \& Rebecca Roiphe, Punishment Without Process: "Victim Impact" Proceedings for Dead Defendants, 88 Fordham L. Rev. 28 (2019).

26 See Office of Justice Programs, Landmarks in Victims' Rights and Services (2018), https://ovc.ncjrs.gov/ncvrw2018/info_flyers/2018NCVRW_Landmarks_508.pdf. 
sexual history and choice of clothing on trial to imply that her "promiscuity" or provocativeness was in some way the cause of what had happened to her. ${ }^{27}$ Reform efforts targeted these problems. ${ }^{28}$

But what came to be known as the victims' rights movement tended to focus more broadly on problems that were not specific to sexual assault cases. For example, other than via their testimony, scripted by the process, victims were voiceless - they did not speak at sentencing and had no right to be informed about the progress of their case as it wended its way through the system. Reformers recognized that in seeking to vindicate the interests of crime victims as well as the public generally, the traditional way of prosecuting criminal cases, including but not limited to sexual assault cases, often caused even greater misery for victims. ${ }^{29}$ In 1980, Wisconsin adopted the first Crime Victims' Bill of Rights, ${ }^{30}$ which was designed to address these problems and other states eventually followed.

Among the most significant milestones in promoting victims' procedural interests in the adjudicative process, as well as more broadly, was President Reagan's appointment of a Task Force on Victims of Crime, which issued a 1982 report recommending 68 new programs, policies, practices and other measures, including a constitutional amendment guaranteeing crime victims "the right to be present and to be heard at all critical stages of judicial proceedings." 31 The report helped energize and chart the course of law reform efforts that have continued to this day. ${ }^{32}$

From the start, the focus of victims' rights efforts has been on employing and improving the criminal adjudicative process, on the assumption that victims, including sexual assault victims, are best served when offenders are prosecuted, convicted and punished harshly. While healing victims was important, reform efforts presupposed that punishing offenders was essential to healing. ${ }^{33}$ The

27 Michelle J. Anderson, From Chastity Requirements to Sexuality License: Sexual Consent and a New Rape Shield Law, 70 GeO. WASHington L. ReV. 51, 52-55 (2002).

28 Id. at 54-55 (but noting that, "[d] espite the advances wrought by the passage of rape shield laws, the chastity requirement survived in a modified form. All rape shield laws admitted evidence of the sexual history between the complainant and the defendant himself.").

29 Ronet Bachman \& Raymond Paternoster, A Contemporary Look at the Effects of Rape Law Reform: How Far Have We Come?, 84 J. CRIM. L. \& CRIMINOLOGY 554, 554-55 (1993) (describing "a fragile alliance among feminist groups, victim's rights groups, and organizations promoting more general 'law and order' themes" to combat stereotypes about "real rape," the historical tendency to blame women and the common practice of putting a woman's sexual history on trial during cross examination).

30 See Dean G. Kilpatrick, Interpersonal Violence and Public Policy: What About the Victims?, 32 J. L. MED. \& ETHICS 73, 77-78 (2004) (providing overview of the crime victims' rights movement).

31 President's Task Force on Victims of Crime, FinAl Report 17-115 (1982) [hereinafter PRESIDENT'S TASK FORCE REPORT].

32 See Shirley S. Abrahamson, Redefining Roles: The Victims' Rights Movement, 1985 UTAH L. Rev. 517, 528 (1985); Lynne N. Henderson, The Wrongs of Victim's Rights, 37 Stan. L. Rev. 937, 943-53 (1985).

33 See, e.g., Steven J. Twist \& Keelah E.G. Williams, Twenty-five Years of Victims' Rights in 
retributive preferences of the victims' rights movement in part reflect its history. The victims' rights movement developed in the context of a call for more prosecutions and harsher criminal punishment - for the decades-long "war on crime" waged by Republican and Democratic presidents alike. It was that bipartisan movement that led to our current regime of mass incarceration, particularly of lowincome men of color. ${ }^{34}$ The restorative justice movement was itself just getting started in the United States in the 1970s and 1980s, when the victims' rights movement was picking up steam. Even more embryonic at that time was the push for diversion programs, problem-solving courts and other alternatives to criminal prosecutions and punitive sentences. ${ }^{35}$

\section{B. The 1982 Task Force Narrative of How the Adjudicatory Process Harms Crime Victims}

From the outset, the law reform efforts of the victims' rights movement, quite understandably, were built on stories, portrayed to be the lived experience of crime victims and their families. Stories have both explanatory and influential powers. But no single story or collection of stories captures the vast, differing and, at times, seemingly contradictory, experiences, perceptions, desires and needs of crime victims. The 1982 Task Force report responded to this challenge by constructing a fictional, composite story of a survivor of a violent crime as she progressed through the criminal process beginning with her report to the police. ${ }^{36}$ The story was said to be based on interviews with crime victims. ${ }^{37}$ For some victims, the fictional account undoubtedly resonated with aspects of their own experience. ${ }^{38}$ But at the same time, the story was a caricature, in that many victims experienced none of the indignities depicted by the Task Force and no victim could have experienced them all. ${ }^{39}$ And

Arizona, 47 Ariz. St. L. J. 421, 446 (2015) (quoting 1990 speech of the founder of Mothers Against Drunk Driving: "Victims don't want vengeance, they want healing; but there can be no healing until justice is done.").

34 See Michelle AleXANDER, The New Jim Crow 13 (2010) (describing mass incarceration as a means to ensure "the subordinate status of a group defined largely by race").

35 John S. Goldcamp, The Drug Court Response: Issues and Implications for Justice Change, 63 Alb. L. REv. 923, 944-46 (2000) (charting the growth of drug treatment courts starting in the late 1980s); see Susan Daicoff, Law as a Healing Profession: "The Comprehensive Law Movement," 6 PEPPERDINE DisP. RESOL. L. J. 1 (2006) (stating that, at the close of the twentieth century, practitioners grew disenchanted with the criminal justice system and created various types of problem-solving courts).

36 PRESIDENT'S TASK ForCE REPORT, supra note 31, at 3-13.

37 Id. at $2-3$.

38 See, e.g., Roberta Roper Interview Transcript, UnIV. OF AKRON, http://vroh.uakron.edu/ transcripts/Roper.php (Last visited Mar. 31, 2020) ("I think the President's Task Force . . . said it best. Victims had little or no role to play if they were fortunate enough to survive the crime .... [T] here were no rights for crime victims.... There were no services.... [W] e were literally on our own ....").

39 See Henderson, supra note 32, at 967 ("The scenario presented in the Final Report is indeed 
there are aspects of the story that seem extreme from today's perspective, given the successes of the law reform movement over the intervening decades.

The Task Force's composite story depicts an "ordeal" that begins with indignities suffered by the victim following a brutal rape by a stranger. In the composite story, the victim suffers further violation at the hands of the police, a nurse in the hospital, and the press, which reports the crime. ${ }^{40}$ The report describes the fictional victim's susceptibility to harm or harassment by the attacker after he is arrested. It then describes the impact on the victim as the adjudicative process progresses from a preliminary hearing through trial, sentencing, appeal and, perhaps, retrial, with the prosecutor inflicting pain, degradation, and inequities upon the victim. The criminal process goes on at length, making it impossible for the victim to put the crime behind her and reconstruct her life. She submits to repetitive questioning by the prosecutor and defense counsel, who make her relive the offender's attack in intimate detail; she is compelled to disclose private information that puts her at risk; and she is subjected to an attack on her character. After the defendant is found guilty, there follows a sentencing hearing in which the defense lawyer minimizes the injuries the offender inflicted, and the sentencing judge denies the victim a chance to speak and announces a lenient sentence. Some victims' rights advocates have referred to the criminal adjudicatory process as a "second rape,"41 and the Task Force's narrative lends credence to this characterization.

To redress the deficiencies described in its story, the Task Force made wideranging recommendations directed at hospitals, the police, and the ministry, among others, ${ }^{42}$ but most importantly at the criminal adjudication process. The Task Force sought to counterbalance the liberal tilt of Supreme Court's criminal procedure decisions that many thought protected the rights of the accused at the expense of justice for crime victims. ${ }^{43}$ The Report's recommendations for law reform included

horrifying. It is also somewhat incredible to anyone acquainted with criminal law practice, and it is insulting to judges, prosecutors, defense attorneys, and law enforcement officers. It is a composite of everything that could go wrong in the process, rather than a chronicle of an actual case. Yet the scenario presented in the Final Report, and other horror stories like it, have led to numerous victim's rights proposals that purport to remedy the situation.").

40 See President's TASK ForCE RePORT, supra note 31, at 3-4.

41 Lee Madigan \& Nancy C. Gamble, The Second Rape: Society's Continued Betrayal OF THE VICTIM 97 (1991).

42 PRESIDENT's TASK FORCE REPORT, supra note 31, at 57-62, 89-96.

43 The application of the exclusionary rule in particular raised the ire of conservatives, including Supreme Court Justices who found themselves in the minority. The Warren Court era rulings began abating in the late 1970s after the election of Richard Nixon, who appointed four Justices who took a less expansive view of criminal defendants' rights. Michael Graetz \& Linda Greenhouse, The Burger Court AND the Rise of the Judicial Right (2016). But the Supreme Court still issued some controversial rulings that strictly applied the exclusionary rule, perhaps most famously in Brewer $v$. Williams, 430 U.S. 387 (1977), where the defendant was convicted for sexually assaulting, kidnapping, and murdering a young girl. By a 5-4 majority, the Court threw out the defendant's confession because it had been obtained in violation of the defendant's Sixth Amendment right to counsel. Chief Justice Burger, in dissent, wrote that the defendant "is guilty of the savage murder of a small child; no member 
requiring that victims' addresses be kept private, that victim counseling be privileged (not subject to discovery), that hearsay be admissible in preliminary hearings so that victims need not testify, that bail laws be made more stringent to protect crime victims during the pretrial period, that victims be promptly notified about developments in their cases, that the Fourth Amendment exclusionary rule be abolished, that witnesses be protected from intimidation, that victim impact statements be required at sentencing; that judges' sentencing discretion be limited, that harsher sentences be imposed, that restitution be required, and that parole be abolished. ${ }^{44}$ The Task Force also directed recommendations to both prosecutors and judges. It encouraged prosecutors to keep victims apprised of the status of the case, bring victims' views to the court's attention, prosecute as harshly as possible those who harass or intimidate victims or witnesses, and discourage continuances to push cases to trial as quickly as possible. ${ }^{45}$ It encouraged judges to give equal weight to victims' and witnesses' interests as to those of the accused when ruling on requests for continuances, allow for, and give appropriate weight to, crime victims' input at sentencing, ordinarily order restitution to victims who suffered financial loss, and ordinarily allow victims and their families to attend the trial even if they will be witnesses. ${ }^{46}$

To some extent, the Task Force's recommendations were directed at preventing or mitigating harms caused by the offender as a consequence of the commission of a violent crime. For example, recommended measures designed to protect victims from harassment or to require convicted offenders to make restitution were plainly aimed at preventing or addressing the offender's blameworthy conduct. But, to a greater extent, the recommendations were meant to prevent or mitigate harms inflicted on the victim by the criminal process itself. For example, the Report recommended protecting the confidentiality of psychological counseling, expanding the admissibility of hearsay to reduce the need for victims' testimony at a preliminary hearing, and assuring victims' information about ongoing proceedings and an opportunity to tell the sentencing judge about the impact of the crime. ${ }^{47}$

Advocating for harsher punishments and more victim-centered protections carried particular resonance in cases of rape and sexual assault. Prior to the early 1980 s, the history of prosecuting rape and sexual assault was often one of blaming women, establishing evidentiary hurdles that made many prosecutions impossible,

of the Court contends he is not." He continued, “Today's holding fulfills Judge (later Mr. Justice) Cardozo's grim prophecy that someday some court might carry the exclusionary rule to the absurd extent that its operative effect would exclude evidence relating to the body of a murder victim because of the means by which it was found. In so ruling, the Court regresses to playing a grisly game of 'hide and seek,' once more exalting the sporting theory of criminal justice which has been experiencing a decline in our jurisprudence." Brewer v. Williams, 430 U.S. 387, 415-16 (1977) (Burger, C.J. dissenting).

44 PRESIDENT's TASK ForCe REPORT, supra note 31, at 17-18.

45 Id. at 63-68.

46 Id. at $72-82$.

47 Id. at 17-36. 
and treating some sexual violations - with the important exception of a rape allegation by a white woman against a black $\operatorname{man}^{48}$ - as relatively minor or even non-criminal. ${ }^{49}$ Through the mid-1970s, most state rape laws did not criminalize spousal rape, and prosecutors routinely made the distinction between "real rape," involving a stranger, and "date rape," involving an acquaintance. ${ }^{50}$ Prosecutors were legally required to prove that the victim actively resisted, and to demonstrate physical injury or provide other corroborating evidence. ${ }^{51}$ In cases that went to trial, victims were cross-examined extensively about their prior sexual history under the theory that it reflected upon their veracity and that seemingly promiscuous women were more likely to be lying. ${ }^{52}$ Under these laws, women coming forward with rape accusations - with the important exception of white women bringing allegations against black men ${ }^{53}$ - were disbelieved until they proved otherwise. Feminists

48 The swift conviction and often pre-conviction lynching of black men accused of sexually assaulting white women has a long history in the United States dating back to slavery and continuing through the middle of the twentieth century. See, e.g., SHERILYNn A. IfILl, On THE COURTHOUSE LAwn: CONFronting the Legacy of Lynching In the Twenty-First CENTURY (2007); Lisa LindQuist Dorr, White Women, Rape, AND the Power of Race in Virginia: 1900-1960 (2004). Often black men were murdered by white mobs before their cases went to trial; or if they did go to trial, the trial itself was a sham. To this day, black men are more likely to receive stiffer sentences and more likely to be falsely convicted of rape than white men. Samuel P. Gross et al., Exonerations in the United States 1989-2003, 95 J. CRIM. L. \& CRIMINOLOGY 523, 546-51 (2005) ("Nobody would be surprised to find that bias and discrimination continue to play a role in rape prosecutions.").

49 Estelle Freedman, Redefining Rape: The Struggle Against Sexual Violence in the ERA of Suffrage And Segregation 10-21 (2013).

50 Bachman \& Paternoster, supra note 29, at 554-55.

51 Michelle J. Anderson, Women Do Not Report the Violence They Suffer: Violence Against Women and the State Action Doctrine, 46 Vill. L. REV. 907, 924-25 (2001). The Model Penal Code issued in 1962 required that an accuser demonstrate more than "token initial resistance." see Michelle J. Anderson, Reviving Resistance in Rape Law, 1998 U. ILL. L. ReV. 953, 966 (1998); Susan Estrich, Rape, 95 YAlE L. J. 1087, 1105-32 (1986) (collecting cases); Barbara Bradley Hagerty, American Law Does not Take Rape Seriously, The ATLANTIC (Jan. 28, 2020), https://www.theatlantic.com/ ideas/archive/2020/01/american-law-rape/605620/ (quoting an expert who stated that through the 1960 s, "[r]ape laws in most states were written in such a way as to make rape virtually impossible to prosecute.").

52 Harriett R. Galvin, Shielding Rape Victims in the State and Federal Courts: A Proposal for the Second Decade, 70 MinN. L. REV. 763, 765-66 (1986); Rebekah Smith, Protecting the Victim: Rape and Sexual Harassment Shields Under Maine and Federal Law, 49 ME. L. REv. 443, 452 (1997).

53 See Donna Coker, Crime Logic, Campus Sexual Assault, and Restorative Justice, 49 TEX. TECH. L. REV. 147, 168 (2016) (discussing racial bias that infects how black men are treated in the criminal justice system and noting that "[a] number of scholars have expressed concern that racial bias may affect [] outcomes in campus sexual assault adjudication[s]" particularly when the accused is a low-income black male athlete presumed to by "hypersexual" and a "thug"); Frank Rudy Cooper, Against Bipolar Masculinity: Intersectionality, Assimilation, Identity, Performance, and Hierarchy, 39 U.C. DAVIS L. REV. 853, 857 (2006) (describing the entrenched stereotype of African American men as "animalistic, sexually depraved, and crime prone"); N. Jeremi Duru, The Central Park Five, the Scottsboro Boys, and the Myth of the Bestial Black Male, 25 CARDOzo L. REV. 1315, 1322-32 (2004) (charting the history of black men being portrayed as bestial sexual predators, the prevalence of lynching black men accused of sex crimes against white women, and what Professor Randall Kennedy 
working within the victims' rights movement aimed to change that mindset, particularly when it came to the orientation of prosecutors and judges.

\section{Ensuing Decades of Reform Efforts}

Although victims' rights advocates have not succeeded in securing a federal constitutional Victims' Rights Amendment, ${ }^{54}$ they have made significant progress in promoting state and federal laws designed to promote crime victims' interests. ${ }^{55}$ Some laws and other advances to assist crime victims are not targeted specifically at the adjudicative procedure - for example, laws to establish and fund social programs, counseling services and compensation for crime victims. ${ }^{56}$ But, with victims' interests at heart, other laws augment or alter the criminal adjudication process. These include state and federal statutes and state constitutional amendments designed to ensure that crime victims are kept abreast of developments in the case, can attend trials, and can give input to the prosecutor and the sentencing judge. ${ }^{57}$ Additionally, over the years, the Supreme Court, presumably influenced by the victims' rights movement, has issued various opinions interpreting constitutional provisions more favorably to victims' interests. ${ }^{58}$

As Marie Gottschalk explains in her book The Prison and the Gallows, "Women and women's organizations played a central role in the consolidation of this conservative victims' rights movement that emerged in the 1970s in the United States." 59 With respect to sex offenses, perhaps the best known reform to the adjudicatory process in the early years of the movement was the adoption of rape shield laws, which place strict limits on the admissibility of evidence concerning a

calls the "legal lynching" of black men in court trials devoid of due process).

54 There are voluminous scholarly writings on proposed victims' rights amendments, which have been periodically debated in Congress. See, e.g., Richard Barajas \& Scott A. Nelson, The Proposed Crime Victims' Federal Constitutional Amendment: Working Toward a Proper Balance, 49 BAYlor L. ReV. 1 (1997); Paul G. Cassell, Barbarians at the Gates: A Reply to the Critics of the Victims' Rights Amendment, 1999 UtaH L. ReV. 479 (1999); Robert P. Mosteller, The Unnecessary Victims' Rights Amendment, 1999 Utah L. Rev. 443 (1999); Steven J. Twist, The Crime Victims' Rights Amendment and Two Good and Perfect Things, 1999 Utah L. REV. 369 (1999).

55 Among the most demanding and extensive state laws concerning victims' rights in the criminal adjudicative process are those of Arizona and California. See ARIz. Const. art. II, § 2.1 (West); CAL. CONST. art. I, § 28 (West); ARIZ. Rev. STAT. §§ 13-4401-13-4443 (2012); see generally Geoffrey Sant, "Victimless Crime" Takes on a New Meaning: Did California's Victims' Rights Amendment Eliminate the Right to Be Recognized as a Victim?, 39 J. LEGIS. 43 (2012); Twist \& Williams, supra note 33 .

56 See, e.g., 42 U.S.C. $§ 10601$ (2008) (establishing Crime Victims Fund).

57 See, e.g., Victim and Witness Protection Act of 1982, 18 U.S.C. $§ 1501,1512$ (1982); Victims' Rights Clarification Act of 1997, 18 U.S.C. $§ 3481$ (1997); Justice for All Act of 2004, 18 U.S.C. § 3771 (2012). See also Kesha Handy, Federal Crime Victims' Rights, 46 Hous. LAw. 14 (2009).

58 See, e.g., Maryland v. Craig, 497 U.S. 836 (1990); South Carolina v. Gathers 490 U.S. 805 (1989); Booth v. Maryland, 482 U.S. 496 (1987).

59 Marie Gottschalk, The Prison and The Gallows 11 (2006). 
victim's sexual history. ${ }^{60}$ By 1978 , when Congress passed the Privacy for Protection of Rape Victims Act, half of the states already had rape shield laws in place; the federal statute was seen as a model for those that did not. ${ }^{61}$ Today, courts generally cannot allow such evidence for the purpose of probing a victim's "character for truthfulness" or "lack of consent." 62

From the perspective of crime victims in general, among the states thought to have the most protective criminal procedure laws is California, with its incorporation of a victims' bill of rights into the state constitution and its strengthening of these provisions several years ago with the adoption of Marsy's Law. ${ }^{63}$ The California state constitution now lists seventeen "personally held and enforceable rights" of crime victims, among which are: the right to protect private information from discovery; the right to refuse defense requests for discovery; the right to confer in advance with the prosecutor about the charges and any pretrial disposition; the right to attend public proceedings; the right to be heard at proceedings regarding (among other subjects) the defendant's plea, sentence, and pretrial release; the right to a speedy trial and a prompt and final conclusion of the case; the right to be notified of material events in the case; the right to restitution; and the right to be informed of the victim's rights. ${ }^{64}$

With respect to sexual assault victims in particular, contemporary law-reform efforts are directed, in part, at redressing procedural problems by reforming the substantive criminal law. For example, to curtail sentencing judges' discretion to impose lenient sentences, California enacted legislation in 2016 imposing mandatory minimum sentences for sexual assault and prohibiting probationary sentences in cases involving oral or vaginal penetration. ${ }^{65}$ This was largely a response to the notorious "Stanford rape case," in which a white affluent college

60 Fed. R. Evid. 412; NAT'L Dist. Attorney's Ass'N, RAPE Shield StATUtes AS OF MarCh 2011, https://ndaa.org/wp-content/uploads/NCPCA-Rape-Shield-2011.pdf (last visited September 3, 2019) (compiling state rape shield laws); see generally Dianne Obritsch, Utah Adopts Rule of Evidence 412: Prohibiting Public Exposure of a Victim's Sexual Past, 21 J. CONTEMP. L. 96 (1995); Smith, supra note 52 at 457-72 (describing the passage of the Privacy Protection for Rape Victims Act by the U.S. Congress in 1978, which established Federal Rule of Evidence 412, a federal rape shield statute, and enactment of a similar state law in Maine).

61 Kathleen Winters, United States v. Shaw: What Constitutes An "Injury" Under the Federal Rape Shield Statute, 43 U. MiAmi L. ReV. 947, 967-86, n.152 (1989).

62 Privacy Protection for Rape Victims Act, Pub. L. No. 95-540, 92 Stat. 2046 (1978); FED. R. EVID. 412. Instead, past sexual history evidence is ordinarily admissible only to show: (1) the perpetrator was someone other than the accused or (2) the existence of a pre-existing consensual sexual relationship between the complaining witness and the defendant. There is a final catchall exception: (3) evidence may be admitted if excluding it would violate the constitutional rights of the accused. Anderson, supra note 27, at 55-56 (citing FED. R. EvID. 412).

63 See CAL. Const. art. I, § 28; see generally Ryan S. Appleby, Proposition 9, Marsy's Law: An Ill-Suited Ballot Initiative and the (Predictably) Unsatisfactory Results, 86 S. CAL. L. REV. 321 (2013).

64 See CAL. Const. art. I, $\S 28$.

65 Cal. Penal Code $\S 263.1$ (West 2017); Cal. Penal Code $§ 1203.065$ (West 2019). 
athlete who was convicted of sexually assaulting an unconscious woman received a sentence of six months instead of the six years requested by the prosecutor, prompting national outrage and the judge's recall from office. ${ }^{66}$

Reform efforts have gained momentum in the wake of the \#MeToo movement; for example, in 2019, New York passed the Child Victims Act, which extends the statute of limitations in sexual assault cases. ${ }^{67}$ Some post \#MeToo efforts to reform the substantive law, particularly with regard to sexual offenses, are meant to ameliorate the difficulty prosecutors conventionally encounter in proving guilt beyond a reasonable doubt in light of the typical absence of witnesses other than the accused and the accuser ${ }^{68}$ Recognizing that it is not feasible to undermine, directly, the presumption of innocence, which is constitutionally protected and universally accepted, reformers have sought, indirectly, to ease prosecutors' burden of proof by redefining the conduct comprising sexual assault under the criminal law. In particular, reformers have sought to criminalize sexual activity in the absence of affirmative consent, ${ }^{69}$ so as to align the normative expectations of the criminal law with those of some university and college codes of student conduct. ${ }^{70}$

66 See Niraj Chokshi, After Stanford Case, California Governor Signs Bill Toughening Penalties for Sexual Assault, N.Y. TIMES (Sept. 30, 2016), https://www.nytimes.com/2016/10/01/us/ sentencing-law-california-stanford-case.html.

67 N.Y. S. B. 2440 (2019-2020), https://legislation.nysenate.gov/pdf/bills/2019/S2440 (last visited Sept. 3, 2019); See Knoll, supra note 24 (describing New York State's passage of the Child Victims Act in 2019, which extends the statute of limitations on sexual assault crimes so that prosecutors can file charges up until the accused turns 28).

68 See, e.g., Mary Wood, City Attorney Shares the Reality of Prosecuting Sexual Assault Cases, U. OF VA. SCH. OF L., https://www.law.virginia.edu/news/2001_02/zug.htm (last visited Sept. 3, 2019) (describing a presentation at the University of Virginia School of Law by a veteran sex crimes prosecutor in Charlottesville, Virginia, who "said rape cases are notoriously hard to try in part because of the burden of proof; there are usually only two witnesses to the crime[:] the victim and the defendant.").

69 Beginning in 2012, the American Law Institute (ALI) debated whether to revise the Model Penal Code's definition which currently recognizes that consent to sexual activity may be "implied"that is, communicated through silence or lack of action. A proposed alternative would require "affirmative consent," which could be demonstrated only through words or actions. Letter from Am. L. Inst. Members to Robert M. Carlson, Esq., President, Am. Bar Ass'n (Aug. 8, 2019). The proposal met with "great controversy," with some ALI members arguing that an affirmative consent standard criminalized innocent conduct, including the "largely tacit ways that people engage in sexual behavior in the real world." Id. (citing to Professor Stephen Schulhofer's Tentative Draft No. 2 (Apr. 2016)). In 2016, the ALI rejected the affirmative consent definition and instead adopted a Model Penal Code definition of consent that included "both action and inaction." A similar debate in the American Bar Association is ongoing. Its governing body recently tabled a proposed resolution urging "legislatures and courts to define consent in sexual assault cases as the assent of a person who is competent to give consent to engage in a specific act of sexual penetration, oral sex, or sexual contact, to provide that consent is expressed by words or action in the context of all the circumstances . ..." ABA Comm. on Domestic \& Sexual Violence, Resolution 114 (2019).

70 See Jeremy Bauer-Wolf, Lawyers' Group Disagrees on College Model of 'Affirmative consent', INSIDE HIGHER ED. (Aug. 14, 2019), https://www.insidehighered.com/news/2019/08/ 14/american-bar-association-tables-new-definition-consent-criminal-sex-assault-cases; KC Johnson \& Stuart Taylor, Jr., Will the ABA Reject Due Process?, WALl ST. J. (Aug. 11, 2019), 


\section{Concluding Thoughts}

As this brief history reflects, the movement to promote crime victims' interests in the criminal process is nowhere near completion. The work advanced by the 1982 Task Force to make the criminal process more hospitable to crime victims continues, and efforts have also moved into new directions. Overwhelmingly, however, criminal procedure reform takes criminal adjudication as a given and presupposes that incarcerating offenders - what might be called the carceral solution - is essential to redress the harm to their victims.

In the next Part of this article, we question this central premise of victims' rights laws, because in many cases, the criminal process both harms victims and deprives them of what they need: agency after the ultimate experience of powerlessness, and healing from trauma. The traditional adjudicatory process is an adversarial one. It must be, to comply with the guarantees provided to criminal defendants in the Fifth, Sixth, and Fourteenth Amendments. It is not focused on and is often irreconcilable with granting victims' agency or a means of healing. The focus is squarely on the defendant, who is incentivized to deny responsibility or minimize culpability to avoid a conviction or obtain a more favorable plea offer. Competent counsel routinely advise clients to admit only the barest facts necessary for the acceptance of a plea. The victim's role is circumscribed, pre-scripted, and limited to testifying when there is a trial and making a victim impact statement at sentencing. While there may be some cathartic power to these acts, there is also harm, harm from the questioning of the victim's account during cross examination and defense counsel's closing statement, and harm from the silence or conflicting statements of the defendant in response to that testimony or to a victim impact statement.

\section{THE FUNDAMENTAL HARMS UNADDRESSED OR UNDER-EMPHASIZED BY VICTIMS' RIGHTS LAWS}

As previously discussed, the victims' rights movement has sought in various ways to make the criminal adjudicative process less hostile to crime victims. However, the movement, and the laws it promoted, fail to address fundamental harms to victims that are inherent in our constitutionally constructed adversarial process of criminal adjudication aimed at identifying and punishing offenders. We begin in Section A with a counter-narrative-a short composite story that serves as a counterpoint to the one on which the 1982 Task Force report built its recommendations. Drawing on our alternative account, Part B briefly emphasizes five ways in which victims can be deeply harmed in our adjudicative process as it is now constructed. Notwithstanding four decades of victims' rights reforms, victims are denied the opportunity to pursue restorative, rather than retributive, justice; they are deprived of agency regarding the criminal prosecution and their role in it; they 
are denied control in particular over their own voices and stories; they can be compelled to suffer psychological harm, including self-harm, as witnesses; and both the prosecution and the defense can intrude into their privacy, including into their confidential communications with therapists and other health care professionals. Amidst all this they have no right to a lawyer to advocate for their interests and their protection. Finally, Part $\mathrm{C}$ explains why these harms are unaddressed, or inadequately addressed, by victims' rights laws.

\section{A. Counter-Narrative of How the Adjudicatory Process Harms Crime Victims}

The 1982 Task Force report could have told a different story, with different emphasis, depicting how crime victims suffer in the criminal process. Emphasizing other harms may not have led to a different set of recommendations, because other harms may seem irremediable or because there may be no political will to address them. But a different story with a different emphasis might have underscored the incompleteness of the proffered recommendations and the limited ability of those recommendations, when implemented, to serve the needs of some victims. A different narrative, focused on different needs and acknowledging the diversity among victims might have inspired a search for an alternative to employing an adversarial means to a retributive end as the principal public response to crime. Consider the following narrative. It, too, is extreme; purposefully so, to draw out crucial contrasts with the Task Force narrative.

The victim was sexually assaulted by an acquaintance - in this case, by another student when they were both intoxicated. They live in the same community and share a common set of friends. They are both non-white, on full scholarship, come from under-served communities, and are the first in their families to attend college. The assault the victim experienced was traumatic, and more trauma was to follow. ${ }^{71}$

Initially, the victim was uncertain whether to report the offense. ${ }^{72}$ She dreaded not only the reactions of her family and friends, and of the offender's friends who were her acquaintances, and how she would be treated by the police and other authorities, but also how she would be treated in the criminal process if the offender were to be prosecuted and she were to be a witness. Many in her situation would

71 Her ensuing experience, while not universal, is common among crime victims. Similar experiences may be shared by, among others, a minor who had a consensual sexual relationship with a young adult, or a parent who was physically abused by a spouse or domestic partner, or a young man who was shot or stabbed by a rivalrous member of the same community after a heated exchange of words.

72 Many crimes go unreported, including almost half of the crimes of gun violence and more than half of property crimes. See generally RACHEL E. MORGan \& JENNIFER L. TRUMAN, U.S. DEP'T. OF Justice, CRIMINAL VictimizATION, 2017, at 4, 7 (2018), https://www.bjs.gov/content/ pub/pdf/cv17.pdf. Rape and sexual assault are among the most under-reported crimes. See CALLIE Marie Rennison, U.S. Dep't of Justice, Rape and Sexual Assault: Reporting to Police and Medical Attention, 1992-2000, at 1 (2002) ("Most rapes and sexual assaults against females were not reported to the police. Thirty-six percent of rapes, $34 \%$ of attempted rapes, and $26 \%$ of sexual assaults were reported to police, 1992-2000.”). 
not report the offense. ${ }^{73}$ But, perhaps supported by some of her friends or family, she decided to do so.

Afterwards, however, as it became increasingly clear that her fears about her experience of the criminal process would be realized, she regretted notifying the police and concluded that she did not want a prosecution to go forward. ${ }^{74}$ In this jurisdiction, the prosecutor privileges the preferences of certain crime victims who want to "drop the charges": for example, the prosecutor would ordinarily defer to a store owner who did not want to charge a shoplifter, whether because the owner was motivated by sympathy or mercy for a member of the community who broke the law, seeking to preserve the goodwill of other members of the community who are customers, or looking to avoid the financial burden of having to serve as a witness. ${ }^{75}$ But the prosecutor, while sympathetic to the victim, questioned whether she appreciated what the criminal process offered, believing sincerely that a prosecution and a conviction was in her best interest. ${ }^{76}$

73 Sexual assault victims' reasons for not reporting vary. See NAT'L SEXUAL Violence Resource Ctr., Statistics About Sexual Violence (2015), https:/www.nsvrc.org/sites/default/ files/publications_nsvrc_factsheet_media-packet_statistics-about-sexual-violence_0.pdf (stating that among the reasons why rape and sexual assault victims do not report to law enforcement are concern for not being believed, fear of the attackers getting back at him/her, embarrassment or shame, fear of being blamed, pressure from others not to tell, distrust of law enforcement, belief that there is not enough evidence, and desire to protect the attacker). Undocumented immigrants in particular tend to under-report crimes out of fear of adverse immigration consequences. See, e.g., Suzan M. Pritchett, Shielding the Deportable Outsider: Exploring the Rape Shield Law as Model Evidentiary Rule for Protecting U Visa Applicants as Witnesses in Criminal Proceedings, 40 HARV. J. L. \& GENDER 365, 366-68 (2017).

74 At least at one time, the reverse situation was more typical: A victim who would be willing to testify will be persuaded by the police or prosecutor that charges should not be brought because a conviction is unlikely. See Frohmann, supra note 16; see also Wayne A. Kerstetter, Gateway to Justice: Police and Prosecutorial Response to Sexual Assaults Against Women, 81 J. CRIM. L. \& CRIMINOLOGY 267, 285 (1990) (finding that sexual assault complainants will be more willing to prosecute when the accused is in custody and there is corroboration).

75 Cf. Ric Simmons, Private Plea Bargains, 89 N.C. L. REv. 1125 (2011) (describing and analyzing private resolutions between crime victims and offenders).

76 Prosecutors do not "represent" victims as clients, but represent "the state" or "the people"; consequently, prosecutors have no obligation to credit victims, to seek to serve victims' interests as distinct from prosecutors' perception of broader public interests, or to take direction from victims or seek to achieve their objectives. See generally Jeffrey J. Pokorak, Rape Victims and Prosecutors: The Inevitable Ethical Conflict of De Factor Client/Attorney Relationships, 48 S. TEx. L. REv. 695 (2007). An empirical study more than two decades ago described that, even before meeting putative victims of sexual assault, prosecutors made initial judgments about whether to bring a prosecution based on the likelihood of securing a conviction, following a review of the investigative file and investigators' advice; based on their initial assessments, when they first met with victims, prosecutors either elicited information for potential use in a prosecution or sought to persuade the victim that a prosecution should not be brought because a conviction would be too difficult to obtain. Frohmann, supra note 16. A contemporaneous study suggested that prosecutors' judgments about the likelihood of a conviction were based on anticipated juror reactions to the evidence and therefore reinforced juror biases based on race, class and gender. Lisa Frohmann, Convictability and Discordant Locales: Reproducing Race, Class, and Gender Ideologies in Prosecutorial Decisionmaking, 31 L. \& Soc'Y. REV. 531 (1997); see 
It is not uncommon for prosecutors to strongly encourage victims to press forward with criminal charges when victims regret having set the process in motion. Prosecutors are operating in good faith: they have put time and effort into the case, believe they can prove it, and believe that justice and public safety will best be served by a conviction and prison sentence. But victims in a situation like this one may in fact have any number of reasons for wanting to call a halt to the prosecution. The victim may: have sympathy for the offender and not want to ruin the offender's life; want to preserve a relationship with the offender; or want to defer to friends or family members who are discouraging a prosecution. ${ }^{77}$ In this case, however, the victim had two other reasons.

First, the victim did not want retribution, but something else. Punishing the offender would bring no comfort, it would make matters worse, including exacerbating her guilt about her own choices leading up to the offense. The victim felt some responsibility despite being told that only the offender was to blame. ${ }^{78}$ To aid in the psychological healing process, the victim wanted an explanation from the offender, an acknowledgment of wrongdoing, an apology, and efforts to make amends. ${ }^{79}$ A prosecution put an end to those options. The offender got a lawyer who made it clear to the victim that she could not speak to his client under any circumstances. The victim, meanwhile, might have been given a trained rape advocate to support her through the criminal process but had no means to retain a lawyer to offer legal advice or help her extricate herself.

Further, the victim desperately did not want to testify, believing that being compelled to do so would compound the misery experienced so far. She did not want to relive a painful or embarrassing experience publicly. She did not want to offer an account only to have it poked, prodded and distorted in court by the prosecutor and defense lawyer. She feared she would be blamed-her intoxication

also Elizabeth Anne Stanko, The Impact of Victim Assessment on Prosecutors' Screening Decisions: The Case of the New York County District Attorney's Office, 16 L. \& SoC'Y REv. 225, 237 (1981) (concluding that prosecutors' implicit use of "[s]ocial class, sex, race, and life style" as factors in making charging decisions often reflects the "pragmatism of a prosecutor intent on maximizing convictions and using organizational resources efficiently.").

77 Coker, supra note 53, at 195, nn. 25-26 (citing the findings of scholars that some victims "don't want to ruin a person's life" but rather want their harm to be validated and to "have choice and input into the resolution of their violation."); Elizabeth E. Joh, Narrating Pain: The Problem with Victim Impact Statements, 10 S. CAL. INTERDISC. L. J. 17, 28 (2000) (discussing the failure of the victims' rights movement to accept "narratives in which victims' families can exercise mercy, kindness, or forgiveness towards defendants.").

78 Audrey K. Miller et al., Deconstructing Self-Blame Following Sexual Assault: The Critical Roles of Cognitive Content and Process, 16 Violence Against Women 1120, 1122 (2010) (providing reasons victims blame themselves, which include a perceived inability to say no, drinking to excess, and consenting to sexual contact prior to the unwanted sexual contact); Coker, supra note 53, at 19495 (describing the power of restorative justice to help victims "overcome feelings of shame-shame from conduct that made them [uniquely] vulnerable ....").

79 Kathleen Daly, Restorative Justice and Sexual Assault: An Archival Study of Court and Conference Cases, 46 BRIT. J. CRIMINOLOGY 334, 337 (2006). 
and her prior relationship, however distant, with the accused used to show that she consented, led him on, or otherwise failed to behave responsibly and appropriately. She was not ready to go public. She didn't want someone else deciding where and how her story would be told - and certainly not in court, in response to lawyers' questions, piecemeal, confined by rules of evidence, punctuated by objections. The victim wanted an empathetic audience, friends, and family predisposed to believe and sympathize, not a dozen strangers on a jury whom a judge instructed to presume that the offender was innocent and so who were obligated to listen skeptically to her account. She reasonably feared that it will be painful to be subject to questioning by a defense lawyer, a skilled advocate whose profession and professional loyalties require trying to make witnesses appear to be mistaken, confused or even deliberate liars. She anticipated that testifying will be a psychological agony that will set back a long healing process that is barely underway. The victim wanted no part of the trial and the public ordeal it entailed.

This prosecutor, however, believed that the offender should be prosecuted regardless of what the victim wanted. ${ }^{80}$ The prosecutor's view was that, when a case of this type was winnable, it was important to bring the case to court, both to punish and incapacitate the offender and to deter others. The prosecutor was sympathetic to this victim but felt compelled to speak for all victims, aiming to vindicate a collective victim interest. The prosecutor has a number of reasons for thinking that what this victim wanted was not what was best for her or for victims generally. ${ }^{81}$ For example, the prosecutor believed that: deferring to vulnerable victims' preferences would encourage offenders and their cohorts to pressure victims not to testify to or withdraw their accusations; it was important to take a hard line with

80 Although prosecutors may take account of victims' preferences among other considerations, prosecutors ordinarily do not privilege the preferences of crime victims and are not expected to do so. See Bruce A. Green, Prosecutorial Discretion: The Difficulty and Necessity of Public Inquiry, 123 DiCKINSON L. REV. 589, 612 (2019).

81 The literature on the prosecution of domestic violence addresses prosecution policies regarding reluctant victim-witnesses. Some prosecutors will forego criminal charges or seek to prove them without the victim's testimony, but others will insist on the victim testifying, and some will even use the threat of imprisonment to compel reluctant victims to testify. See Deborah Epstein et al., Transforming Aggressive Prosecution Policies: Prioritizing Victims' Long-Term Safety in the Prosecution of Domestic Violence Cases, 11 Am. U. J. GendER, Soc. PoL'y \& L. 465 (2002); Cheryl Hanna, No Right to Choose: Mandated Victim Participation in Domestic Violence Prosecutions, 109 Harv. L. Rev. 1849 (1996); Thomas L. Kirsch II, Problems in Domestic Violence: Should Victims Be Forced to Participate in the Prosecution of Their Abusers?, 7 WM. \& MARY J. OF WOMEN \& L. 383 (2001); Linda G. Mills, Intuition and Insight: A New Job Description for the Battered Woman's Prosecutor and Other More Modest Proposals, 7 UCLA WoMEN's L. J. 183 (1997); Meg Obenauf, The Isolation Abyss: A Case Against Mandatory Prosecution, 9 UCLA WoMEN’s L. J. 263 (1999). See generally Frank W. Miller, Prosecution: The Decision to Charge a Suspect with a Crime 173 (1970) ("An important factor considered by prosecutors in making day-to-day decisions whether to charge is the expressed desire of the victim of the crime."). Prosecutors' greater willingness to prosecute, notwithstanding the victim's reluctance, in domestic violence cases as compared with sexual assault cases, likely reflects the greater ease of securing a conviction in a domestic violence case without the victim's testimony or with the testimony of a hostile victim-witness. See N.Y. S. B. 2440 (2019-2020), https://legislation.nysenate.gov/pdf/bills/2019/S2440 (last visited Sept. 3, 2019). 
regard to certain crimes to redress law enforcement authorities' historic indifference; unsophisticated crime victims - particularly young people-were not wellpositioned to act in their own best interest, especially their long-term best interest, because they had incomplete or stereotypical understandings of the criminal process. Perhaps the prosecutor was sensitive to the history of rape prosecutions in which the state's discretionary decisions have been made disparately based on irrelevant and impermissible considerations - for example, statistics showing that sexual assaults committed against women of color are less likely to be prosecuted than sexual assaults committed against white women. ${ }^{82}$

If the case were not winnable at trial, the prosecutor might have dropped the charges or bargained them down to virtually nothing, even if the victim insisted on prosecuting to the hilt. ${ }^{83}$ But the opposite was true here. The prosecutor not only personally believed the victim but was hopeful that a jury would find her credible. Without the victim's testimony, however, there was no case. The constitutional right of confrontation and evidentiary rules on the inadmissibility of hearsay precluded the prosecutor from relying instead on the victim's out-of-court statements to the police and others. ${ }^{84}$ Only by credibly threatening to take the case to trial could the prosecutor secure a guilty plea as part of a fair plea bargain.

The victim left school and relocated, partly because the public nature of the case had brought with it unwelcome attention that made it impossible to resume her regular life, and in part to make it harder for the prosecutor to find her and bring her to court as a witness. But the prosecutor had an investigator find her and subpoena her to testify in court. ${ }^{85}$ The prosecutor threatened that if the victim ignored the subpoena, she would be arrested and sent to jail as a "material witness" until the trial, even while the offender was out on bail. ${ }^{86}$ The prosecutor also warned the

82 Coker, supra note 53, at 155. ("A recent national survey of service providers and advocates found widespread police dismissiveness and hostility toward intimate partner violence and sexual assault claims by sex workers, drug-involved women, poor women (particularly poor women of color), undocumented immigrant women, African American women, and LGBT[Q] individuals.”).

83 See supra text accompanying note 76; see also Tamara Rice Lave, The Prosecutor's Duty to “Imperfect” Rape Victims, 49 TEX. TECH L. REV. 219 (2016) (criticizing prosecutors' reluctance to bring cases involving victims who they think juries will not find credible); Jeffrey W. Spears \& Cassia C. Spohn, The Genuine Victim and Prosecutors' Charging Decisions in Sexual Assault Cases, 20 Am. J. CRIM. JUST. 183 (1996) (finding that Detroit prosecutors' charging decisions in sexual assault cases were influenced by victim characteristics, including conformity with traditional gender role expectations and prompt reporting, associated with "genuine" victims).

84 See generally Tom Lininger, Prosecution Batterers After Crawford, 91 VA. L. REV. 747 (2005) (discussing Confrontation Clause decision impeding the admissibility of victims' extrajudicial statements); Anoosha Rouhanian, A Call for Change: The Detrimental Impacts of Crawford v. Washington on Domestic Violence and Rape Prosecutions, 37 B.C. J. L. \& Soc. Just. 1 (2017) (same).

85 Even victim-witnesses who leave the jurisdiction may be brought back to testify. See, e.g., People v. Cogswell, 227 P.3d 409 (Cal. 2010) (finding that prosecutor may compel out-of-state victimwitness's appearance through the Uniform Act to Secure the Attendance of Witnesses from without the State in Criminal Cases).

86 Emily Shugarman, Rape Survivors Face Jail If They Won't Testify in Louisiana, INDEPENDENT (Apr. 21, 2017), https://www.independent.co.uk/news/world/americas/rape-victims- 
victim that she would be jailed for civil contempt of court if she disobeyed the judge's order to testify, and she could then be prosecuted, convicted and imprisoned for criminal contempt of court. ${ }^{87}$

The accused rejected a plea offer and went to trial, where the victim very reluctantly testified. The defense lawyer cross-examined her skillfully. Although the rape-shield law barred gratuitous questioning about her sexual history, and, after procedural skirmishing, the court barred the defense lawyer from reading her therapist's notes and those of a victim's advocate with whom she spoke in the prosecutor's office, the rest of her life was an open book. The defense lawyer questioned the victim in detail about her allegations, including probing everything she said and did about it afterwards, as well as about anything she did before or since that might be used to make her appear unworthy of being believed. Contrary to the prosecutor's hopes, the jury acquitted the defendant. ${ }^{88}$

Meanwhile, the community in which the victim and the offender both live was roiled by the case. The victim was exposed to angry outbursts from those who believed that she was ruining a promising young man's life. Having been scarred by the cross-examination, the victim viewed the verdict as a rejection. She sunk deeper into depression. ${ }^{89}$

Over the course of this process, the victim was told more than once about the state law that codifies a crime victims' rights. ${ }^{90}$ The victim had the opportunity to confer with the prosecutor, ${ }^{91}$ but the prosecutor was uninterested in what she had to say after she expressed her desire not to move forward with a criminal case. The victim had the right to watch the entire trial, but she could think of nothing worse.

survivors-face-jail-if-dont-testify-court-louisiana-attorney-leon-cannizzaro-a7694061.html (quoting Orleans Parish District Attorney Leon Cannizzaro saying, "If I have to put a victim of a crime in jail, for eight days, in order to . . keep the rapist off of the street, for a period of years and to prevent him from raping or harming someone else, I'm going to do that.”). Cf. Schneyder v. Smith, 653 F.3d 313 (3d Cir. 2011) (civil action for alleged unconstitutional detention of a material witness).

87 Cf. In re Collins, 195 So. 3d 1129 (Fla. 2016) (sanctioning judge who held victim in contempt of court for violating trial subpoena).

88 The conviction rate for criminal prosecutions in general is high in many jurisdictions. But the conviction rate for certain offenses, such as assault, is lower than for other offenses. See FAQ Detail, Bureau OF Justice Statistics, https://www.bjs.gov/index.cfm?ty=qa\&iid=403 (last visited Mar. 31, 2020) (reporting that among felony defendants, over a one-year period, the conviction rate was lowest for defendants charged with assault (45\%)).

89 Criminal trials do not invariably re-traumatize crime victims. See Ulrich Orth \& Andreas Maercker, Do Trials of Perpetrators Retraumatize Crime Victims?, 19 J. INTERPERSONAL VIOLENCE 212 (2004). But victims who are dissatisfied with the outcome of the criminal trial are more likely to experience psychological harm. See Uli Orth, Secondary Victimization of Crime Victims by Criminal Proceedings, 15 Soc. Just. RES. 313 (2002).

90 Victims' rights laws generally require prosecutors or other law enforcement authorities to advise victims of their rights. See, e.g., UtAH CODE AnN. § 77-37-3(3)(d) (West 2019) (requiring the law enforcement agency investigating a sexual offense to victims of their statutory rights).

91 See, e.g., United States v. Stevens, 239 F. Supp. 3d 417 (D. Conn. 2017) (rejecting plea agreement where prosecutor failed to provide victim's mother an opportunity to confer in advance as required by the Crime Victims’ Rights Act, 18 U.S.C. $\S 3771(a)(5)$ (2012)). 
The state had a lawyer and the accused had a lawyer, but she was never assigned a lawyer to advise her, to try to persuade the prosecutor to spare her the agony of testifying, and to help her assert whatever rights she had. ${ }^{92}$

If the offender had been found guilty, the victim might have been able to tell the judge her story in a less circumscribed fashion - though not necessarily entirely in her own way. ${ }^{93}$ But she never got that chance, and in any event, she was more interested in speaking privately with a therapist than publicly with a judge. After her long ordeal, she did finally get one thing she wanted all along from the criminal process - to be left alone. But the offense remained a living memory as did the painful criminal process that followed it from the day she reported the offense until the offender's acquittal.

\section{B. The Under-Emphasized Harms to Victims}

As the composite narrative in Section A reflects, five fundamental harms to victims were overlooked or downplayed in the 1982 Task Force report. They were not addressed in the Task Force recommendations or in the laws pursued by victims' rights advocates in the succeeding decades. These harms are not caused by the offender, except perhaps indirectly by setting the criminal process in motion. They are caused by the criminal adjudicative process itself and by its participants in their quest for punishment. Though underemphasized by proponents of a victims' rights amendment and similar reforms, these harms have garnered significant attention from those who seek to reform the criminal process in more fundamental ways, including by expanding the pursuit of restorative justice. ${ }^{94}$

92 Victims' rights laws do not generally provide for the appointment of counsel to victims. See generally Margaret Garvin \& Douglas E. Beloof, Crime Victim Agency: Independent Lawyers for Sexual Assault Victims, 13 OHIO St. J. CRIM. L. 67 (2015); Myka Held, A Constitutional Remedy for Sexual Assault Survivors, 16 GeO. J. Gender \& L. 445 (2015); Erin J. Heuring, Til It Happens to You: Providing Victims of Sexual Assault with Their Own Legal Representation, 53 IDAHO L. REV. 689 (2017); Tyrone Kirchengast, Victim Lawyers, Victim Advocates, and the Adversarial Criminal Trial, 16 New CRIM. L. REV. 568 (2013). Further, the laws generally limit the extent to which victims' privately retained lawyers can intervene in criminal proceedings to assert victims' rights and protect their interests. See generally Douglas E. Beloof, The Third Wave of Crime Victims' Rights: Standing, Remedy and Review, 2005 BYU L. REV. 255 (2005). That role is principally assigned to the prosecutor, notwithstanding the universal understanding that the prosecutor does not represent the victim as a client. See generally Stacy Caplow, What If There Is No Client?: Prosecutors as "Counselors" of Crime Victims, 5 CLINICAL L. REV. 1 (1998); Pokorak, supra note 76.

93 See, e.g., Graham v. State, 440 P.3d 309 (Alaska Ct. App. 2019) (sentencing judge improperly allowed victims' families to play memorial videos that appealed to judge's emotions). For a discussion of whether the court may give putative victims a chance to make "impact statements" in court after an untried defendant's death, see Green \& Roiphe, supra note 25.

94 See, e.g., Hadar Dancig-Rosenberg \& Tali Gal, Restorative Criminal Justice, 34 CARDOZO L. Rev. 2313 (2013); Jean Ferguson, Professional Discretion and the Use of Restorative Justice Programs in Appropriate Domestic Violence Cases: An Effective Innovation, 4 AM. U. CRIM. L. BRIEF 3 (2009); Zvi D. Gabbay, Justifying Restorative Justice: A Theoretical Justification for the Use of Restorative Justice Practices, 2005 J. DisP. RESOL. 349 (2005); Mary Ellen Reimund, The Law and Restorative Justice: Friend or Foe? A Systemic Look at the Legal Issues in Restorative Justice, 53 
First, the criminal process denies the victim an opportunity to pursue a form of justice - restorative justice - that may be more important to her than the retributive justice achieved by traditional criminal adjudications. The criminal process holds out the promise of a conviction and prison sentence for the offender. But the victim's psychological well-being may be better served in a restorative justice process, if the offender is equally willing to undertake it. In a restorative justice process, supportive community members participate, the victim can tell her story her way, and the offender acknowledges and apologizes for the harm he caused, shows insight into his behavior, accepts responsibility, and takes affirmative steps to repair the harm and not to harm others. ${ }^{95}$ Restorative justice may be employed at various stages of a criminal process, ${ }^{96}$ but our focus is on its use as an alternative to a criminal adjudication and incarceration - that is, on the diversion of offenders to a restorative justice process just as defendants in drug cases are diverted to drug courts where they agree to drug treatment instead of a prosecution and potential incarceration. As an alternative to criminal prosecution and punishment, restorative justice is premised on the belief that prison is a blunt and ineffective instrument illsuited to achieving its aims. The criminal process encourages the offender to deny or minimize responsibility thus thwarting the needs of some victims for accountability and repair. ${ }^{97}$

Second, the criminal process denies the crime victim agency or autonomy; after suffering a criminal offense that left her feeling disempowered, the victim loses control over how the offense will be addressed. ${ }^{98}$ The victim cannot require the prosecutor to "drop the charges" or refuse to testify if the prosecution goes forward. Defense counsel may call the victim as a witness if the prosecutor does not do so. ${ }^{99}$

DraKe L. REV. 667 (2005); SERED, supra note 10; Strang \& Sherman, supra note 20, at 20-21.

95 See SERED, supra note 10, at 96-253.

96 In some jurisdictions, for example, restorative justice follows a defendant's guilty plea, and its outcome is factored into the judge's sentencing decision. A program established in 2015 by U.S. District Court Judge Leo Sorokin in federal district court in Boston requires defendants facing serious though non-violent felony charges to plead guilty before entering into an 18-month long program that includes drug treatment, if necessary, enrollment in school or obtaining or maintaining a job, and participation in a court-run restorative justice program. Most of the defendants who enroll in this program are facing at least several years in prison. Those who successfully complete the program are usually sentenced to probation. Lara Bazelon, Redemption for Offenders and Victims, AMERICAN PROSPECT (Jan. 18, 2018), https://prospect.org/health/redemption-offenders-victims/. The program does not accept defendants accused of sexual assault offenses, however.

97 While victims might theoretically pursue restorative justice after criminal proceedings are concluded, the opportunity may be entirely unavailable at that point. The offender, if convicted at trial, may appeal and will not want to compromise that appeal by making admissions. If the offender is not convicted, he or she will likely want nothing further to do with the case. Even if restorative justice is available post-trial, the victim may suffer further from the delay and the additional trauma that proceeded it.

98 For academic writings on victims' loss of agency, see e.g., Garvin \& Beloof, supra note 92, at 69-72; Kirchengast, supra note 92.

99 See, e.g., A.H. v. Super. Ct. of Ariz., 911 P.2d 633 (Ariz. Ct. App. 1996). 
As long as there is sufficient evidence to justify a prosecution, the decision whether to bring charges and whether to compel the victim to testify is up to the prosecutor.

It was not always this way. In the early days of the Republic, as a carryover from the English tradition, private prosecutions gave victims more influence over the prosecuting decision. ${ }^{100}$ But by the twentieth century, that largely changed. ${ }^{101}$ Prosecuting is now in the hands of public prosecutors. Theoretically, and as a matter of discretion, and evidence permitting, prosecutors could defer to crime victims regarding whether to bring charges, offer a plea bargain, or call the victim as a witness. ${ }^{102}$ But while some victims' rights laws require prosecutors to confer with victims about these decisions, none require prosecutors to defer to victims. ${ }^{103}$ Prosecutors do not represent the victim per se. They represent the interests of "the People," "the Commonwealth" or "the Government" and are expected to act in the best interests of that larger group even if it conflicts with the interest of an individual victim. ${ }^{104}$

Third, victims have no control, in particular, over how they or the lawyers at trial tell their story. ${ }^{105}$ Constitutional, statutory and evidentiary provisions provide a framework governing how victims' stories can be told. Prosecutors, through direct examination, and defense lawyers, through cross-examination, elicit the information they require. Through their opening and closing statements, these lawyers then give meaning to the testimony, characterize it, credit or discredit it, digest it and explain it to the jury. Victims' stories do not belong to them in the criminal process. Once the prosecutor decides to call a victim as a witness, the victim's story is shaped and appropriated by others.

Fourth, victims have no right to protection from self-harm. The compulsion that they testify, subject to civil and criminal contempt, means that they can be forced to hurt themselves psychologically by submitting to public interrogation. Criminal defendants have a right against self-harm in the form of self-incriminatory testimony; they can refuse to testify in the adjudicative process. ${ }^{106}$ Crime victims

100 See Darryl K. Brown, Criminal Enforcement Redundancy: Oversight of Decisions Not to Prosecute, 103 MinN. L. REV. 843 (2018); Michael Edmund O'Neill, Private Vengeance and the Public Good, 12 U. PA. J. Const. L. 659 (2010).

101 Bennett Capers, Against Prosecutors, 105 CoRnEll L. REV. (forthcoming 2020).

102 Id.

103 See, e.g., United States v. Stevens, 239 F. Supp. 3d 417 (D. Conn. 2017) (rejecting plea agreement where federal prosecutor failed to give the victim's family an opportunity to confer with the prosecutor in advance, as required by the Crime Victims' Rights Act, 18. U.S.C. § 3771(a)(5)).

104 Lara A. Bazelon, Hard Lessons: The Role of Law Schools in Addressing Prosecutorial Misconduct, 16 BERKELEY J. CRIM. L. 391, 410 (2011) ("Unlike a defense attorney, whose sole object is to advance the interests of her client, prosecutors have no living, breathing individual for whom to advocate. Contrary to popular belief, the prosecutor does not represent the crime victim, at least not any more directly than she represents her next-door neighbor. The prosecutor's client is an impersonal monolith: the state, county, or federal government.").

105 See, e.g., Nils Christie, Conflicts as Property, 17 Brit. J. CRIMINOlogY 1 (1977).

106 U.S. Const. amend. V; see, e.g., Doyle v. Ohio, 426 U.S. 610 (1976) (reversing defendant's 
have no equivalent right. No matter how much they may be hurt psychologically by having to testify, the decision is not theirs. It is, principally, that of the prosecutor.

Fifth, victims' privacy is subject to intrusion by both the prosecution and the defense. Rape shield laws are not an absolute barrier to the inspection and exposure of deeply private information. ${ }^{107}$ Even victims' medical and mental health records may be subject to discovery and introduced into evidence at trial, notwithstanding the ordinary expectation that communications with healthcare professionals are confidential. ${ }^{108}$ State laws do not necessarily recognize an absolute privilege for communications with a therapist or other medical professional, and healthcare records may therefore be subject to discovery, particularly if they are likely to assist in the defense. ${ }^{109}$

Finally, victims are on their own. Most cannot afford to retain counsel, and are not afforded a lawyer to advise them, to advocate on their behalf with the prosecutor, or to help them take advantage of whatever legal protections may be available. ${ }^{110}$ It is axiomatic that individuals with legal rights need lawyers to help implement those rights. Individuals embroiled in the criminal justice process, if only as witnesses, benefit from legal advice; consequently, corporations commonly compensate lawyers to represent officers and employees who are witnesses in both civil and criminal cases involving the corporation. ${ }^{111}$ But the Victims' Rights Amendments that are periodically re-introduced in Congress do not include a right to counsel for crime victims. The victims' rights movement has not made a right to counsel a priority.

conviction where prosecutor impeached his exculpatory story with his failure to give that story postarrest and after invoking his right to silence); United States v. Hale, 422 U.S. 171, 182-83 (1975) (White, J., concurring) (holding that a prosecutor may not hold a defendant's post-Miranda invocation of silence against him at trial).

107 Alison Menkes, Rape and Sexual Assault, 7 GeO. J. GeNDER \& L. 847, 849-50 (2006) (noting the ineffectiveness of rape shield laws to protect against disclosure of a victim's "sexual and psychological history").

108 Tess Wilkinson-Ryan, Admitting Mental Health Evidence to Impeach the Credibility of a Sexual Assault Complainant, 153 U. PENN. L. REV. 1373, 1374 (2005) (noting that defendants may request "a review of [the] complainant's mental health history, a mental [health] examination, or crossexamination as to a history of psychological problems."); Jeffrey Toobin, The Consent Defense, NEW YORKER (Aug. 25, 2003), https://www.newyorker.com/magazine/2003/09/01/the-consent-defense (discussing Colorado's rape shield laws in connection with the defense of consent raised by Kobe Bryant's lawyers after he was accused of rape).

109 See, e.g., Commonwealth v. Dwyer, 859 N.E.2d 400 (Mass. 2006); see also Meagen K. Monahan, Note, Why Dwyer Got It Wrong: A Call to Rebalance the Scale and Protect Absolute Privileged Communications Between Sexual Assault Victims and Counselors, 96 B.U. L. REV. 1523 (2016).

110 UtAH CODE ANN. § 77-37-3(3)(d) (West 2019).

111 See N.Y.C. Bar Comm. on Prof'l Ethics, Op. 2019-4 (2019) (addressing ethical implications of corporation's payment of a single "pool counsel" to represent multiple officers or employees as witnesses in an investigation.). 


\section{The Limitations of Victims' Rights Law}

The victims' rights movement called attention to victims' interests, called out the historically gendered and even misogynistic nature of sex crimes prosecutions, and obtained significant social and legal reforms for all victims and sex crimes victims in particular. ${ }^{12}$ These are important achievements. But, as the prior sections suggest, there are significant limitations to criminal procedure reforms that have been enacted so far, and to the federal constitutional Victims' Rights Amendment that might one day become the movement's crowning achievement. ${ }^{113}$

The criminal procedural reforms initiated by victims' rights advocates take our criminal adjudicative process as both a given and a point of departure. The goal was never to offer an alternative but to improve the criminal process for crime victims' benefit. One underlying assumption of the reform effort, as we have noted, was that the preferred resolution, from all victims' perspective, was a criminal conviction and a severe, retributive sentence. ${ }^{114}$ For many advocates, another assumption was that, regardless of the outcome, the criminal process might well be inevitable if victims went to the police, and so the best that could be done for crime victims was to try to limit how much the process harmed them. ${ }^{115}$

As we will examine, both assumptions are challenged by some victims and by proponents of restorative justice processes, who argue that these restorative processes achieve better outcomes for many victims while helping them heal, rather than re-victimizing them. ${ }^{116}$ Among other things, restorative justice processes aim to avert the above-discussed harms that are intrinsic to adversarial adjudication. This is not to say that restorative justice is suitable or preferable in all cases. On the contrary, victims' situations vary. Sometimes, victims will prefer a criminal prosecution to go forward and will benefit from its success; sometimes, the public interest in a criminal prosecution should outweigh the victim's interest in an alternative; and sometimes, restorative justice is not a viable alternative because of

112 Estrich, supra note 51, at 1092 (describing a history of rape law prosecutions in which, when it was not a violent stranger rape, "the woman must bear any guilt, the law has reflected, legitimized, and enforced a view of sex and women which celebrates male aggressiveness and punishes female passivity."); Smith, supra note 52, at 455-59 (documenting "changes in both substantive and evidentiary rules of rape law.").

113 See Supra note 54 (citing academic literature on proposed Victims' Rights Amendments).

114 Research has not borne out this assumption. See e.g., Strang \& Sherman, supra note 20, at 18 n.11 ("Many victims are, in fact, quite 'lenient' in their own views about sentencing. Large proportions of crime victims surveyed are willing to consider alternatives to imprisonment for their offenders if they can play a part in the way their case is handled.") (citing Lucia Zedner, Victims, in The OXford HANDBOOK OF CRiminology, 419, 443-44 (Mike Maguire et al. eds., 2002)).

115 Cf. Christa Obold-Eshleman, Note, Victims'Rights and the Danger of Domestication of the Restorative Justice Paradigm, 18 Notre DAME J. L. Ethics \& PuB PoL'Y 571, 594 (2004) (observing that "the current victims' rights laws and proposals are developing largely in a way that is problematic for the restorative justice vision.").

116 Strang \& Sherman, supra note 20, at 15, 22 (citing studies showing that "evidence for the success of restorative justice in repairing the harm of crime is rapidly accumulating."). 
the character of the offender. There are victims who want aid, social services, and restitution without participating in a criminal adjudicatory process. There are also victims who want no part of any process at all — restorative or adjudicatory. But proponents argue that restorative justice is often preferable for at least some victims; not only in cases of less serious crimes or juvenile offenders, where it is more likely to be employed (though still underutilized) in the United States, but also in cases of violent crimes (including sexual assaults), which have conventionally been considered the most serious and therefore the most deserving of a retributive public response. ${ }^{117}$

The victims' rights movement's focus on criminal adjudication and retributivism owes much not only to its history but also to politics. ${ }^{18}$ Efforts to reform the criminal process for victims' benefit needs the support of multiple branches of government. Its success depends on legislative funding for social programs and, with respect to reforming the criminal process in particular, on legislative support except in the few jurisdictions, such as California, where public referendums are an alternative. Further, the movement has sought changes in prosecutorial and judicial practices. It calls for victim-centered judicial interpretations and applications of constitutional and statutory provisions. These reforms require sympathetic prosecutors and judges. But from the start, public officials saw an opportunity to coopt the victims' rights movement in aid of a broader conservative agenda. An example was the Presidential Task Force's proposal to reform the Fourth Amendment. ${ }^{119}$ The suppression of evidence in criminal cases was not a problem that related particularly to crimes with victims, but anything that made it easier to secure criminal convictions could potentially be characterized as a victim-centered reform.

For at least two reasons, the movement's success has depended, in particular, on securing the support of prosecutors. First, when it comes to the development of criminal law, prosecutors have enormous influence with legislators and judges. Legislators view prosecutors as particularly knowledgeable and experienced, and as representatives of the public interest. Second, proponents of victims' rights laws have had to walk a tightrope: their argument for more process turns in part on the implication that prosecutors have ill-served victims. Indeed, the campaign for a Victims' Rights Amendment was founded on the idea that prosecutors have failed to afford victims the protections guaranteed by statutes. At the same time, however, victims' rights advocates also have to make the case that their interests and the prosecutors' interests were aligned. That is, victims' rights advocates have also had to convince prosecutors that their proposed reforms were consistent with

117 See, e.g., SERED, supra note 10, passim.

118 Gruber, supra note 12, at 771-74 (stating that the victims' rights movement was coopted by the tough on crime movement, neither of which had any "tolerance for victims' desires that conflict with state prosecutorial goals.").

119 PREsident's TASK Force RePORT, supra note 31, at 17, 24-28. 
prosecutors' objectives and would not excessively burden them. ${ }^{120}$ To maintain the symbiotic relationship, victims' rights advocates were compelled to embrace retributivism. Prosecutors, in turn, relied on the victims' rights movement to bolster their claim that locking up offenders was the best way to serve the most vulnerable and deserving people.

Prosecutors could generally accommodate contemporary victims' rights laws, which work within the basic structure of the criminal adjudicatory process. Even prosecutors who viewed these laws as burdensome knew that it is politically perilous to be seen as opposing them. Thus, the implicit bargain between victims' rights proponents and prosecutors was struck in the 1980s. Victims' rights advocates secured prosecutors' support for victims' rights laws that, in turn, preserved prosecutors' power by reaffirming the criminal adjudicative process within which they operated. ${ }^{121}$

Perhaps that was the best deal that victims' rights advocates could obtain in the 1980s and ensuing years. But the result is that, largely for reasons of political expediency, the contemporary victims' rights movement focuses its efforts on victims' rights laws, such as Marsy's Law, that does nothing to address some of the most fundamental and serious harms inflicted on crime victims by the criminal adjudicative process. ${ }^{122}$

120 This was no easy task and has not been entirely successful. An obligation to provide information to victims throughout the process is time-consuming and takes resources away from work that prosecutors may regard as more important. And while giving victims a voice with regard to plea bargaining or sentencing may support prosecutors' efforts, victims may also interfere with what the prosecutor considers to be in the best interest of the public overall. Michael Lyle, Marsy's Law: Sounds Good, But Is It?, NevADA CURRENT (Aug. 31, 2018), https://www.nevadacurrent.com/2018/08/31/ marsys-law-sounds-good-but-is-it/ (quoting the executive director of the North Dakota State's Attorneys Association as critical of the law for its vagueness, the expense of implementing it, and possibly slowing down the adjudication of cases).

121 Aya Gruber, The Feminist War on Crime: The Unexpected Role of Women's LIBERATION IN MASS INCARCERATION 7 (forthcoming 2020).

122 What would happen if at least some prosecutors became supportive of restorative justice practices as an alternative to the carceral solution? We expect that conventional prosecutors will perceive efforts to establish restorative justice processes, in the name of victims' rights, as an existential threat for multiple reasons on which we will elaborate in a later article. Suffice it to say that it seems likely that conventional prosecutors will vehemently oppose reforms that would diminish their power and discretion by diverting criminal cases to processes, such as restorative justice processes, controlled by social service agencies and community representatives. 


\section{THE MYTH OF THE MONOLITHIC VICTIM AND THE FAILURE OF THE CARCERAL SOLUTION}

Any process built on the assumption that victims are a monolithic group who all want and need to see the offender convicted and harshly punished is deeply flawed. ${ }^{123}$ But advocates for victims' rights reform have historically operated from this premise. ${ }^{124}$ To be sure, since the 1970 s and continuing through the present, victims' advocates have rightly pointed out that the existing system of rape prosecutions is cumbersome, unfair, and misogynistic. ${ }^{125}$ They successfully sought changes to that process meant to address those impediments, imbalances, and biases. But reckoning with the shameful history of rape prosecutions in the United States has led to both an over- and an under-correction. The answer to every sexual assault victim is not for prosecutors to hold out the same ill-kept promise- "we will relieve your pain by prosecuting your offender to the maximum possible extent"-while victims' rights advocates nod vigorously in agreement. ${ }^{126}$

The promise is ill-kept for two reasons. First, as we discuss below, there is scant evidence to suggest that punishing an offender to the maximum possible extent ameliorates the suffering of victims. ${ }^{127}$ To the contrary: studies show that any satisfaction victims may experience from such an outcome is temporary and not conducive to the healing process. ${ }^{128}$ Second, the conviction rate for rape and sexual

123 See Gruber, supra note 12.

124 Markus Dirk Dubber, The Victim in American Penal Law: A Systemic Overview, 3 Buff. CRIM. L. REV. 3, 6 (1999) (describing the Victims' Rights Movement as "fueled by grassroots campaigns of concerned citizens backed by politicians eager to outdo their opponents in the tough-oncrime competition"); Gruber, supra note 12, at 772 ("As a tool of tough-on-crime penological goals, the victim must occupy a specific, predefined legal space, such that granting her 'rights' will necessarily lead to more incarceration for the defendant.").

125 Bachman \& Paternoster, supra note 29, at 555; Julie K. Brown, Justice Department Opens Probe into Jeffrey Epstein Plea Deal, MiAmi HeRALD (Feb. 6, 2019), https://www.miamiherald.com/ news/nation-world/article225624945.html (describing how Jeffrey Epstein, a millionaire financier with connections to former President Clinton and other powerbrokers, obtained a deal from federal prosecutors in 2008 that allowed him to avoid a trial and lengthy prison sentence on sex trafficking charges).

126 Gruber, supra note 12, at 749-50 (describing how the victims' rights movement became increasingly aligned with prosecutors tough on crime agendas at the expense of the victims themselves); Sofie Karasek, I'm a Campus Sexual Assault Activist. It's Time to Reimagine How We Punish Sex Crimes, N.Y. TIMES (Feb. 22, 2018), https://www.nytimes.com/2018/02/22/opinion/campus-sexualassault-punitive-justive.html (writing that as a survivor of sexual assault, she believes that "punitive justice," including prison, "is not designed to provide validation, acknowledgement or closure" and is not a guarantee that the offender will stop offending).

127 Ulrich Orth, Does Perpetrator Punishment Satisfy Victims' Feelings of Revenge?, 30 AgGressive BeHAVIOR 62, 68 (2004).

128 Susan Bandes, When Victims Seek Closure: Forgiveness, Vengeance and the Role of Government, 27 FordHAM URB. L. J. 1599, 1602-03 (2000) (noting the lack of empirical evidence to support the premise that victims require severe punishment of offenders to heal); SERED, supra note 10, at 40 ("[T]ime after time, victims tell the parole board that they still feel exactly the way they did the day the crime occurred. Ten, fifteen, twenty years later - they feel the same."); Interview with Stepheny 
assault remains notoriously low, estimated at approximately 12 percent in 2007, and less than one percent from 2010-2014. ${ }^{129}$ Rape retains the dubious distinction of being "the least reported, least indicted and least convicted non-property felony." 130 For non-white victims, the outcomes are grimmer still. Because of implicit and explicit biases, police are less likely to refer their cases for prosecution, prosecutors are less likely to bring charges, and jurors are less likely to convict. ${ }^{131}$ In short, nonwhite victims, particularly those who suffer from poverty and substance abuse and who have criminal records, fare differently and worse at every stage of the criminal justice system. ${ }^{132}$

Women of color, trans women, and women in the LGBTQ community are invisible in the public narrative about rape, and less likely to have their interests

Milo (June 28, 2019) (Milo's son, Matthew Seivert, was senselessly murdered in 2003. She said that, 16 years later, she feels exactly the same amount of rage and pain) (on file with Lara Bazelon).

129 Andrew Van Dam, Less Than 1\% of Rapes Lead to Felony Convictions. At least 89\% of victims face emotional and physical consequences, WASH. Post (Oct. 6, 2018), https://www.washingtonpost.com/business/2018/10/06/less-than-percent-rapes-lead-felony-

convictions-least-percent-victims-face-emotional-physical-consequences/ (citing an analysis by RAINN, which in turn relied on data gathered by the DOJ from 2010-2014); Mary Koss \& Mary Achilles, Restorative Justice Responses to Sexual Assault, NAT'L Online Resource CTR. FOR Violence AgAinst Women, at 4 (Feb. 2008), https://pdfs.semanticscholar.org/4dd0/82fbebcf20665 eacf2f8e9447678974a09ae.pdf?_ga=2.111463556.1440798903.1567804160-1316325837.

1545245920 (reporting a $12 \%$ conviction rate for rape in the United States, according to 2007 data).

${ }^{130}$ DAvid R. Karp et Al., CAmpus PRISM: A Report on Promoting Restorative Initiatives for Sexual Misconduct on College Campuses 8-9 (2016) (internal quotations omitted) (stating that only 13 percent of victims of campus sexual assaults report them and the lack of reporting "can be exacerbated for students of color and LGBTQ students who may have low expectations that the institutional process will be responsive to their needs"); Koss \& ACHILLES, supra note 129, at 4.

131 Elizabeth Kennedy, Victim Race and Rape: A Review of Recent Research, FEMINIST SEXUAL ETHICS PROJECT 18-30, https://www.brandeis.edu/projects/fse/slavery/united-states/slav-us-articles/ kennedy-full.pdf. Mining data in Kansas City and Philadelphia revealed that "prosecutors were 4 1/2 times more likely to file charges if the victim was white." Id. at 14. A study of 900 cases in Indianapolis concluded that "[b]lack men accused of assaulting black women accounted for 45 percent of all reported rapes, but for only 26 percent of all men sentenced to the state penitentiary and for only 17 percent of all men who received sentences of six or more years. By contrast, black men accused of assaulting white women accounted for 23 percent of all reported rapes, but for 45 percent of all men sent to the state penitentiary and for 50 percent of all men who received sentences of six or more years." Id. at 16. Moreover, black women are "significantly less likely" to report having been sexually assaulted to the police than white women in part because "[t]he credibility of Black women as rape victims has never been established as firmly as it has for White women." Gail Elizabeth Wyatt, The Sociocultural Context of African American and White Women's Rape, 48 J. Soc. Issues 77, 86 (1992).

132 Kennedy, supra note 131, at 11 ("The overwhelming majority of studies confirm that the victim's race plays a significant role throughout the process of investigating and prosecuting rape crimes: specifically, these studies suggest that African American women who are victims of rape encounter a legal system that perceives them and the seriousness of their injuries differently because of their race."); Koss \& ACHILLES, supra note 129, at 4 (2008) (stating that decisions whether to prosecute are "unduly influenced" by factors that include "class, race, character, conduct, mental health, sexual history, lack of injury, failure to manifest extreme emotional distress, and absent evidence of strong resistance"). 
represented in the courtroom. ${ }^{133}$ The stereotypical rape victim is a young innocent white woman violently raped by a black male stranger. ${ }^{134}$ Yet cross-racial stranger rapes are a fraction of sex crimes overall. ${ }^{135}$ No victim could represent the group as a whole, but this particular kind of essentialism - the victim must be an innocent white woman brutally raped by a bestial black man-plays on racial and gender stereotypes and tends to result in an embrace of the carceral solution as necessary, deserved, and effective. ${ }^{136}$ In fact, inter-racial sexual violence is rare; far more common are intra-racial non-stranger sexual assaults. ${ }^{137}$ Victims are a diverse group: sexual violence occurs across race, ethnicity, geographic area, sexual orientation and socioeconomic class. Men are also victims of rape and sexual assault, ${ }^{138}$ and trans women and LGBTQ women are at a particularly high risk. ${ }^{139}$ Ignoring these victims

133 GRUBER, supra note 121 (describing the ideal victim from the perspective of the feminist movement as a middle class innocent white woman and stating that "[w]omen who fell outside that idea were often not helped, or even harmed, by policies tailored for [that ideal victim].”); BETH RICHIE, Arrested Justice: Black Women, Violence, and America's Prison Nation 90 (2012); Sered, supra note 10, at 204-06 (citing studies and stating that we often fail to tell the stories of victims who are not white and heterosexual or "[w] hen we do tell them, we do so in a distorted way").

134 Sharin N. Elkholy, Feminism and Race in the United States, INTERNET ENCYCLOPEDIA OF Philosophy, https://www.iep.utm.edu/fem-race/ (last visited Aug. 25, 2019); Lynne Henderson, Coopting Compassion: The Federal Victim's Rights Amendment, 10 St. Thomas L. Rev. 579, 583-85 (1998).

135 SERED, supra note 10, at 22-23 ("In that way, when the image of an innocent white woman is invoked as the prototypical victim, it not only supplants and displaces the lived experience of the vast majority of victims who do not belong to that demographic. It is also meant to conjure up a story about what justice looks like-justice in which the victim is pure and innocent, in which the person who caused harm is heartless and monstrous, in which the prosecutor is righteous and vengeful, and in which the system as we know it contains them all in a rightful and proper order."); See also Aya Gruber, Righting Victim Wrongs: Responding to Philosophical Criticisms of the Nonspecific Victim Liability Defense, 52 Buff. L. REV. 433, 433 (2004) (collecting stereotypes of victims); Vik Kanwar, Capital Punishment as Closure: The Limits of a Victim-Centered Jurisprudence, 27 N.Y.U. REV. L. \& Soc. Change 215, 231 (2002) ("The public face of the Victims' Rights Movement hides the most severely affected victims of violent crime, sexism and racism (e.g., prostitutes or teenage black males in the juvenile justice system) who are implicitly disqualified as 'genuine' victims in Victims' Rights rhetoric.").

136 SERED, supra note 10 at 194-96 (describing the effects of this archetype: black men are hyper-sexualized and portrayed as irredeemable monsters while white women are helpless and dependent on white men for "protection and survival" while black victims' pain is discounted as "somehow outside of and irrelevant to the justice equation").

137 Kennedy, supra note 131, at 10.

138 Sexual Assault of Men and Boys, RAPE, ABUSE \& INCEST NAT'L Network, https://www.rainn.org/articles/sexual-assault-men-and-boys (last visited Mar. 1, 2020); Tina Vasquez, \#MeToo: Addressing Sexual Assault and Abuse in Social Justice Movements, REwIRE (Nov. 3, 2017), https://rewire.news/article/2017/11/03/metoo-addressing-sexual-assault-abuse-social-justicemovements/ (describing a case in which a self-identified queer man was raped by another man who was a member of his community).

139 Sexual Assault and the LGBTQ Community, Human Rights CAmpaign, https://www.hrc.org/resources/sexual-assault-and-the-lgbt-community (last visited Mar. 1, 2020) (citing 2015 Transgender Survey and the Centers for Disease Control's 2010 study on victimization 
in the public narrative and treating them as second-class victims in the criminal justice system underscores the need for a different approach. Casting the stereotypical offender as a hyper-sexualized black man preying on a white woman is not only false, it promulgates centuries-old pernicious racial stereotyping. ${ }^{140}$

The narrative set forth at length in the 1982 Task Force report described a victim of violence at a stranger's hands who presumably would be restored to wellbeing through the expeditious arrest, incapacitation, conviction and punishment of the offender. But this paradigm of the crime victim, and underlying assumption that the criminal process can be better calibrated to meet her needs, are flawed. Many crime victims simply do not fit this paradigm, or any other, as sexual assault cases illustrate. Seventy-eight percent of sexual assaults involve victims and offenders who know each other. ${ }^{141}$ Often, they come from the same communities. ${ }^{142}$ More than a third of these cases involve intimate partner violence. ${ }^{143}$ Some of the offenders were victims of sexual violence themselves. ${ }^{144}$ Poor women, both white and non-white, are far more likely to be assaulted than middle or upper class women. ${ }^{145}$ Many victims, particularly from communities disproportionately impacted by mass incarceration, do not want to be part of a criminal process that they view as destructive because it ravages their neighborhoods and breaks apart their families, and because they feel unsafe knowing that the offender will come back to their community unrehabilitated and hardened by prison. ${ }^{146}$ Other victims

broken down by sexual orientation); Coker, supra note 53, at 162-64 (2016) (citing the DOJ's 2016 Campus Climate Survey Validation Study as documenting "significantly higher" rates of sexual assault for LGBTQ women and a 2010 National Intimate Partner and Sexual Violence study finding that "nearly $34 \%$ of multiracial non-Hispanic women and approximately $27 \%$ of indigenous women experienced rape victimization in their lifetime compared to $18.8 \%$ of white non-Hispanic women and $14.6 \%$ of Hispanic women.").

140 Duru, supra note 53, at 1322-32.

141 Michael Planty et al., U.S. Dep't of Justice, Female Victims of Sexual Violence 1994-2010, at 4 (2016). "The NCVS collects information on nonfatal crimes reported and not reported to the police from a nationally representative sample of persons age 12 or older who live in U.S. households." Id. at 2.

142 Id. at 4.

${ }^{143} I d$.

144 Mills, supra note 5, at 481-82 ("Intimate abuse cases are a classic example of victim turned victimizer, insofar as men who experienced and observed violence in their families of origin were five to nine times more likely to become violent against their partners.").

145 Planty ET AL., supra note 141, at 4 (special report issued 2013 and revised 2016) (noting that "females in households earning less than $\$ 25,000$ per year experienced 3.5 rape or sexual assault victimizations per 1,000 females, compared to 1.9 per 1,000 in households earning between $\$ 25,000$ and $\$ 49,999$ and 1.8 per 1,000 in households earning $\$ 50,000$ or more."); SERED, supra note 10 , at 216-18 (describing poor white and working class white neighborhoods as "beset with violence," that includes sexual violence that devastates families and communities).

146 SERED, supra note 10, at 29, 35-36,185-86 (citing examples to explain why for some sexual assault victims "engagement of law enforcement is regarded as likely to increase rather than diminish the threat to their safety and the safety of their families."); Lynne Henderson, Co-opting Compassion: The Federal Victim's Rights Amendment, 10 St. Thomas L. Rev. 579 at 600 (1998) ("The punitive 
may be unwilling to go forward with a criminal prosecution because they move in the same social or professional circles as the offender or because they believe that the offender would benefit from treatment or other rehabilitative programs. ${ }^{147}$ In roughly half of all sexual assault cases both the victim and the perpetrator were under the influence of alcohol, which has "effects on sexual and aggressive behavior, stereotypes about drinking women, and ... cognitive and motor skills." ${ }^{148}$ The point is not to blame the victim or excuse the offender but rather to highlight how fraught, complex, and murky sexual violence can be for both parties. ${ }^{149}$

Sexual assaults are not all essentially the same. The \#MeToo movement, which has raised awareness of the pervasive problem of sexual assault, has also raised awareness of the many forms it can take, from a colleague's "handsiness," to a date's unwanted groping, to a completed rape by an acquaintance, to forced oral sex at gunpoint by a stranger. ${ }^{150}$ \#MeToo has done away with the risible idea that some level of unwanted sexual touching must be tolerated because it is simply not "serious ... enough" to report. ${ }^{151}$ At the same time, as more and more people are exposed for committing a wide array of sexually inappropriate conduct, the

history of oppression, lynching, and harsh treatment by a white-dominated legal system and the damage that system has done to the African-American communities in this country is neither distant nor unreal. To concentrate on revenge and punishment may isolate the victim and create a cruel dilemma for her by demanding she choose between her rage and her community.").

147 Amy B. Cyphert, The Devil is in the Details: Exploring Restorative Justice as an Option for Campus Sexual Assault Responses Under Title IX, 96 DENV. L. REV. 51 (2018) (explaining why some complainants in campus sexual assault cases do not wish to move forward with a campus adjudicatory process); Karasek, supra note 126 (stating that, "putting [the person who assaulted her] in prison seemed almost laughably ill-suited to what I needed. What I wanted was for him to change his behavior. He needed an intervention, not prison.").

148 Antonia AbBey et al., Nat’l Inst. on Alcohol Abuse \& Alcoholism, Alcohol and SEXUAL ASSAULT (2001), https://pubs.niaaa.nih.gov/publications/arh25-1/43-51.htm (stating that the percentages are "conservative"). "Beliefs about alcohol's effects on sexual and aggressive behavior, stereotypes about drinking women, and alcohol's effects on cognitive and motor skills contribute to alcohol-involved sexual assault." Id.

149 Caroline Lippy \& Sarah DuGue, Exploring Alcohol Policy Approaches to Prevent Sexual Violence Perpetration, 17 Trauma Violence \& ABUSE 26, 27 (2016) ("Numerous studies have found a direct association between alcohol use and sexual violence perpetration in diverse populations, including high school and college students, adolescent and adult sex offenders, community men and women, and among individuals in same-sex relationships."); Coker, supra note 53, at 194-95 ("Victims may experience shame because they blame themselves for the assault, believing that ... their drinking was the cause of the assault.").

150 Ann Hornaday, Enough with Naming and Shaming: It's Time for Restorative Justice in Hollywood, WASH. PosT (Feb. 1, 2018), https://www.washingtonpost.com/lifestyle/style/enough-withnaming-and-shaming-its-time-for-restorative-justice-in-hollywood/2018/02/01/416ccf80-0518-11e8b48c-b07fea957bd5_story.html (describing post \#MeToo accusations as ranging from subtle boundary violations and verbal abuse to outright assault and rape); KARP ET AL., supra note 130, at 8-9 (defining campus sexual misconduct as "[A] wide range of offending behaviors such as sexual harassment, stalking, sexual assault, and intimate partner violence.").

151 See Nora Stewart, The Light We Shine into The Grey: A Restorative \#MeToo Solution and an Acknowledgement of Those \#MeToo Leaves in the Dark, 87 FordHAM L. REV. 1693, 1694 (2019). 
shortcomings of the criminal justice system to address the complexity and nuance of the problem become more pronounced. ${ }^{152}$ And even when the offenses are similar or the same, victims differ in their responses.

The victims' rights movement purports to speak for all victims, but it fails to take their multiplicity of needs into account. If the goal is to make victims central in the process of confronting, assessing, and meting out consequences for the harm done, those with power and influence - prosecutors, victims' rights advocates, and other advocacy groups - need to provide victims with alternatives, not an all-ornothing choice. ${ }^{153}$ Better understanding what a particular victim needs in a particular situation may call for the appointment of pro bono counsel so that, like the accused, the victim has someone solely devoted to advocating for her interests. ${ }^{154}$ Better understanding the needs of victims also calls for less coerciveness and stereotyped thinking, and more openness on the part of prosecutors and victims' rights advocates.

Under our current system, victims who report their sexual assaults to the police are presented at most with two options: the potential for a criminal conviction, which may or may not be realized, or nothing at all. ${ }^{155}$ This one-size-fits-all approach is incomplete and ill-suited to many situations no matter the race or socio-economic class or sexual orientation of the victim, and no matter what kind of assault was involved. ${ }^{156}$ At its most functional, the criminal justice system makes victims passive actors in supporting roles. ${ }^{157}$ The trauma they experience is not only due to re-living the event and experiencing intrusions into their personal history, it is also due to their lack of control over the legal process. Their participation at trial is

152 Andrew Dalton, One Year on From \#MeToo, Sexual Misconduct Prosecutions are Still Rare in Hollywood, INDEPENDENT (Oct. 7, 2018), https://www.independent.co.uk/news/world/americas/metoo-hollywood-sexual-misconduct-prosecutions-weinstein-cosby-spacey-a8572066.html (reporting that the Los Angeles District Attorney's Office was considering charges in fourteen cases but citing complications including statutes of limitation and lack of "hard evidence").

153 C. Quince Hopkins et al., Applying Restorative Justice Practices to Ongoing Intimate Violence: Problems and Possibilities, 23 St. Louis U. Pub. L. ReV. 289, 291 (2004) (stating that "existing remedies are problematic because they often base relief on an essentialized conception of a victim" when some victims may not want jail or prison).

154 Erin Gardner Schenk \& David L. Shakes, Into the Blue Yonder of Legal Representation of Victims of Sexual Assault: Can U.S. State Courts Learn from the Military?, 6 U. DenV. CRIM. L. ReV. 1, 25-26 (2016) (arguing that criminal courts should import the military's procedure of appointing special counsel to represent the interests of sexual assault victims); Merle H. Weiner, Legal Counsel For Survivors of Campus Sexual Violence, 29 YALE J. L. \& Feminism 123, 156 (2018) (arguing that sexual assault victims need separate counsel because prosecutors cannot be counted upon to represent the interests of the victim "especially if the victim's needs conflict with the prosecutor's effort to obtain a conviction.").

155 Michelle Alexander, Reckoning with Violence, N.Y. Times (Mar. 3, 2019), https://www.nytimes.com/2019/03/03/opinion/violence-criminal-justice.html; Coker, supra note 53, at 161.

156 Mills, supra note 5, at 458.

157 Stephanos Bibas \& Richard A. Bierschbach, Integrating Remorse and Apology into Criminal Procedure, 114 YALE L. J. 85, 136 (2004). 
dictated by the prosecutor and the focus at all times is squarely on the offender. While a victim impact statement allows victims to try to influence the sentence, the focus is only on consequences and is "presented too late in the justice process to offer victims any real sense of control." 158 No wonder then that so many victims feel disempowered, sidelined, and even erased. ${ }^{159}$ By emphasizing retribution over all else, the criminal process leaves some victims unsatisfied and others worse off. ${ }^{160}$

\section{AN ALTERNATIVE APPROACH}

There are victims of sexual assault who could benefit from a different approach ${ }^{161}$-indeed, there is an argument that it is unethical not to provide one, given the documented failure of the criminal process. ${ }^{162}$ Victims need "a more comprehensive menu of options to facilitate their recovery from crime." "163 What many want is an opportunity to tell their story under their own power, validation of their suffering, accountability from the offender, a promise of change moving forward, and an agreed upon means of repairing the harm done to the victim and to the community. ${ }^{164}$ For some victims, that means voluntarily engaging in a restorative justice process, which can take a variety of forms, including mediated victim-offender dialogues, healing circles, and other, more indirect ways of engagement that offer an opportunity for victims to tell their stories in their own voices under their own agency. ${ }^{165}$

At the heart of the restorative approach is the offender's acknowledgement of causing harm and validation of the victim's suffering, a reckoning with the offending behavior that involves reflection and insight, a commitment not to re-offend, and an agreed-upon means of holding the person accountable. ${ }^{166}$ Some victims want solely, or additionally, restitution, a public apology, access to counseling, and additional measures such as securing safe housing or civil protective orders. ${ }^{167}$ Author and restorative justice practitioner Danielle Sered found that when given a choice, "Do

158 Mills, supra note 5, at 470.

159 Lara Bazelon, Rectify: The Power of Restorative Justice After Wrongful CONVICTION 100-01 (2018) (quoting a victim's cousin as saying, "From the victim's standpoint, it's no longer your case. It's the state's case. For a rape victim, her body isn't even her body anymore, it's a piece of evidence. Even the name of the case belongs to the perpetrator.").

160 Kasparian, supra note 7, at 378.

161 See, e.g., Harrelson, supra note 15; Karasek, supra note 126.

162 SERED, supra note 10, at 41.

163 Mills, supra note 5, at 458.

164 KARP ET AL., supra note 130, at 3, 23-28; SERED, supra note 10, at 23.

165 Ruth E. Fleury, Missing Voices: Patterns of Battered Women's Satisfaction with the Criminal Justice System, 8 Violence AgAinst Women 181, 202 (2002); KARP ET AL., supra note 130, at 2.

166 Koss, The RESTORE Program, supra note 21, at 9.

167 Mary P. Koss, Restorative Justice for Acquaintance Rape and Misdemeanor Sex Crimes, in Restorative Justice and Violence Against Women 218, 221 (James Ptacek ed., 2010). 
you want this [different kind of] intervention or ... prison?," ninety percent of survivors of violent crime in New York City chose the restorative path offered by her organization, Common Justice. ${ }^{168}$

While victims of sexual assault are a diverse group, many share a common objective: assurance that the person who harmed them will not go on to harm more people. ${ }^{169}$ While at first look, it may seem that criminal punishment is a means to achieving that end, it often is not. The criminogenic effect of prison has been well documented; we know that people who go to prison, particularly maximum security prisons for serious violent crimes, can emerge hardened and more violent than when they entered. ${ }^{170}$ Nor do most prisons offer the programmatic and educational opportunities for the insight and self-reflection that are necessary for offenders to grapple with their sexually violent behavior-including hearing directly from the victim or surrogate victims - and take the steps necessary to change that behavior. ${ }^{171}$

What if victims of sexual assault had an alternative that would help them heal, hold offenders accountable, and keep them and their communities safe? Established programs have demonstrated that restorative justice, rigorously applied, is one such alternative even in cases involving extreme violence. ${ }^{172}$ Scholars and psychologists have argued that it makes little sense to exclude sexual assault cases from programs like these, which are survivor-centered and address criminal acts that are deeply and personally violative. ${ }^{173}$ Such a program, like all restorative programs, depends on the voluntary participation of victims, and not all victims will want to engage with it. ${ }^{174}$ But the data suggest that many do, and that restorative justice, unlike criminal justice, is more effective in addressing the root causes of violent crime, making victims whole, reknitting communities, and reducing recidivism. ${ }^{175}$ Insofar as

168 SERED, supra note 10 , at 42-43.

169 SERED, supra note 10 , at 30.

${ }^{170}$ Amy E. Lerman, The People Prisons Make: Effects of Incarceration on Criminal Psychology, in Do Prisons Make Us Safer: The Benefits and Costs of the Prison Boom 151, 151-52 (Steven Raphael \& Michael A. Stoll eds., 2009) (examining the "significant and criminogenic effect of placement in a higher-security prison."); Daniel S. Nagin et al., Imprisonment and Reoffending, 38 CRIME \& JUST. 115, 167 (2009) (stating that "much of the literature points to a criminogenic effect of the experience of imprisonment."); Martin H. Pritikin, Is Prison Increasing Crime?, 2008 WiSC. L. REV. 1049, 1067-69 (2009) (documenting the criminogenic effects of prison).

171 SERED, supra note 10, at 64-67, 78-79.

172 SERED, supra note 10, at 133-34 (listing the types of offenses that her program addresses but stating that sexual assaults are excluded).

173 Cyphert, supra note 147, at 85; Mills, supra note 5, at 498-502; Strang \& Sherman, supra note 20 , at 35 .

174 SERED, supra note 10 , at 28.

175 SERED, supra note 10, at 143 (citing studies and stating that "[r]estorative justice has been shown to leave those harmed more satisfied with outcomes: survivors who have taken part in restorative processes in the United States have reported 80 to 90 percent rates of satisfaction, as compared with satisfaction rates of about 30 percent for traditional court systems."); Koss, The RESTORE Program, supra note 21 , at 12 (documenting that $63 \%$ of sexual assault victims in felony cases and 70 percent in misdemeanor cases agreed to participate in a restorative justice alternative to the criminal process in 
prosecutors seek to do what is best for crime victims, victims of sexual assault who would prefer a non-adjudicative and non-punitive alternative such as a restorative justice process should have that option because it empowers them, helps them heal, and aligns with prosecutorial objectives. Of course, victims do not exercise veto power within the system, and prosecutors may believe in individual cases that other public interests, such as public safety, should take precedence over doing what is in the victim's best interest. Ultimately, it is up to the prosecutor to decide what course of action to take. But barring exceptional cases - for example, cases involving repeat, violent sexual offenders - there is nothing to suggest that a prosecutor who is giving priority to the victim's interests should not honor a victim's restorative justice preference.

The use of restorative justice in sexual assault cases, however, is a rarity, in part because victims' rights advocates believe it lets offenders off the hook too easily and will fail to deter them from re-offending, and that communities are safer when those who commit sexual offenses are locked up. ${ }^{176}$ In fact, the limited data available shows otherwise: in Australia, which applies restorative justice practices in juvenile sexual assault cases, an empirical study of 232 cases showed that "violent crime offenders whose cases were handled through restorative justice practices were $40 \%$ less likely to reoffend than those whose cases went through the criminal justice system." 177 Prosecutors inclined to skepticism when asked to adopt a restorative justice approach ${ }^{178}$ should also pause and consider how the current system has failed

her pilot program in Arizona); Caroline Angel, Crime Victims Meet Their Offenders: Testing the Impact of Restorative Justice Conferences on Victims' Post-Traumatic Stress Symptoms (2005), https://repository.upenn.edu/dissertations/AAI3165634/ (unpublished Ph.D. dissertation, University of Pennsylvania) (on file with the University of Pennsylvania Libraries) (examining restorative justice programs involving robbery, burglary, and assault and finding reduced rates of PTSD among victims who participated vis a vis victims who went through the traditional court system). There are other issues relating to protecting the offender's legal rights that we will address in a later article.

176 Cyphert, supra note 147, at 69-70 (listing concerns); Koss, The RESTORE Program, supra note 21, at 3 (collecting studies); Carrie Johnson, D.C. Prosecutors, Once Dubious, Are Becoming Believers in Restorative Justice, NPR News (July 2, 2019) https://www.npr.org/2019/07/02/ 735506637/d-c-prosecutors-once-dubious-are-becoming-believers-in-restorative-justice (describing one prosecutor's initial reaction this way: "Her first reaction? 'Oh, OK, so we're not going to prosecute you? We're going to sit around in a circle with, like, the hippies down the hallway, and we're going to have a talk and then you don't have any punishment?"').

177 Cyphert, supra note 147, at 70 (citing Alletta Brenner, Transforming Campus Culture to Prevent Rape: The Possibility and Promise of Restorative Justice as a Response to Campus Sexual Violence, HARV. L. J. \& GENDER 1 (2013)).

178 Even restorative justice participants are inclined to dismiss restorative justice practices as "soft on crime" approaches that coddle criminals with kumbaya silliness and generally let them off the hook. BAZELON, supra note 159, at 125-28 (describing Bobby Fitzpatrick, an offender, initially viewing restorative justice as "rainbows and lollipops" only to radically change his views after completing the program). But this blinkered view of restorative justice fails to comprehend how difficult it is to witness firsthand the damage one has inflicted on someone else. As Sered writes, "In a fundamental way, what is required in acknowledging the impact of our actions can be harder-even scarier - than prison." She continues, "it does require of people the one thing prison almost never does: facing the people whose lives they've changed, as a full human being who is responsible for the pain 
and continues to fail victims and society at large, falling far short of prosecutors' objective - namely, achieving justice. ${ }^{179}$ In 2009-2010, the most recent years for which federal data were available, only 32 percent of rapes and sexual assaults were reported to the police. ${ }^{180}$ Of that number, only 5.7 percent resulted in arrests and .07 percent led to a conviction. ${ }^{181}$ In short, fewer than 1 percent of rape allegations result in a criminal conviction. By contrast, the trauma experienced by the victims can be severe, with 65 percent reporting psychological problems including PTSD, anxiety, depression, and fear. ${ }^{182}$

We do not argue that restorative justice should supplant the existing criminal justice process, only that in some cases, where there is not a paramount need to incapacitate a dangerous offender or some other countervailing public interest that should take precedence, it should be offered to victims as an alternative. While existing programs that use restorative justice in cases of extreme interpersonal violence in the United States are limited, the few that exist show promise. Sered's organization, Common Justice, was created in 2008 by the Vera Institute in partnership with the Kings County District Attorney's Office in Brooklyn. ${ }^{183}$ While the program does not include offenders accused of sex crimes, many of its participants have committed extremely serious crimes including shootings, stabbings, and other violent assaults. ${ }^{184}$ If, and only if, the victims agree to participate, they will come together - or use a surrogate to represent them - with the perpetrator "and family and community members with a stake in the outcome." 185 The victims are free to reject the Common Justice alternative, in which case the offenders will go through the court process, and if convicted, serve prison sentences. ${ }^{186}$

One might expect, given the victims' rights narrative about "what victims want," that most victims would reject what Common Justice offers them. ${ }^{187}$ But ninety percent of victims choose the program over the traditional criminal justice process

of others.”). SERED, supra note 10, at 102-03.

179 See supra note 18.

180 Planty ET AL., supra note 141, at 6.

181 Van Dam, supra note 129 (Almost 9 out of every 10 sexual assault victims experience some level of distress, with 46 percent experiencing severe distress - a higher number than we see among victims of robbery or aggravated assault, according to an analysis by Justice Department statisticians Lynn Langton and Jennifer Truman of 2009-2012 figures from the massive annual crime victimization survey mentioned above. Other sources place the figure even higher.).

182 Id.

183 SERED, supra note 10, at 133 (“Guided by restorative justice principles, we offer a survivorcentered accountability process that gives those directly impacted by acts of violence the opportunity to shape what repair will look like, and, in the case of the responsible party, to carry out that repair instead of going to prison.").

184 Telephone interview by Lara Bazelon with Danielle Sered (Nov. 27, 2019).

185 Sered, supra note 20, at 50.

186 Id.

187 SERED, supra note 10, at 42. 
even though offenders will not be sent to prison and will have their felony conviction removed following successful completion of the program. ${ }^{188}$ By 2018, Sered wrote, the number of offenders who engaged in her program had a recidivism rate of only six percent. ${ }^{189}$ From 2012-2018, Common Justice expelled only one person from the program for committing a new crime. ${ }^{190}$

To offer another example: RESTORE, a federally-funded program that operated in Pima County, Arizona from 2003-2007, ${ }^{191}$ worked collaboratively with local prosecutors to offer victims of felony and misdemeanor sexual assaults the opportunity to choose a restorative justice alternative over the traditional criminal process. ${ }^{192}$ Sexual offenses ranged from rape to indecent exposure. ${ }^{193}$ The majority of victims offered this choice accepted the opportunity to participate in RESTORE. ${ }^{194}$ Participation in RESTORE required victims and offenders to participate in a restorative justice conferencing process overseen by program personnel and a facilitator, together with family and supporters. ${ }^{195}$ Victims described how the assault had impacted their lives and the lives of their friends and family. ${ }^{196}$ Offenders took responsibility for committing the assault and also participated in active listening by putting the victims' story into their own words, with the victims correcting them when necessary. ${ }^{197}$ Offenders were held to account through mandatory participation in sex offender therapy, substance abuse treatment where warranted, regular meetings and check-ins with case managers, community service, and restitution. ${ }^{198}$

A study of the program found that of the twenty-two cases accepted over a three-year period, "[t]wo thirds of felony and $91 \%$ of misdemeanor" offenders successfully completed the program. ${ }^{199}$ Two offenders were terminated from the program because homelessness, substance abuse or financial problems prevented them from complying with the requirements; one offender withdrew after reversing

${ }^{188} I d$.

189 Id.

190 Id. at 134.

191 "The program operated from March 2003, to August 2007, and closed at the end of federal funding." Koss, The RESTORE Program, supra note 21, at 10.

192 Hopkins et al., supra note 153, at 302 (explaining that RESTORE was "funded by a $\$ 1.5$ million ... grant from the Centers for Disease Control"). Certain offenders were excluded, including juveniles, those accused of domestic violence, those with arrests for violent crimes excluding sexual assault, and those with repeated histories of sexual assault. Koss, The RESTORE Program, supra note 21 , at 10 .

193 Koss, The RESTORE Program, supra note 21, at 4.

194 Id. at 12.

195 Id. at 8 .

196 Id.

197 Id.

198 Id. at 9.

199 Id. at 32. 
himself and denying responsibility. ${ }^{200}$ Ninety percent of the victims who participated stated that they "were satisfied that justice was done." 201 The percentage of victims suffering from PTSD dropped from $82 \%$ to $66 \%$ after completing the program. ${ }^{202}$ The percentage of participants who "felt safe, listened to, supported, treated fairly, treated with respect, and not expected to do more than they anticipated" exceeded ninety percent. ${ }^{203}$

RESTORE and Common Justice are just two programs in two counties, but their results teach important lessons. First, the under-utilization and selective application of restorative justice practices should be re-examined. Traditionally, restorative justice has been reserved as an alternative only in cases involving juveniles or only for low-level non-violent offenses. ${ }^{204}$ Studies and successful programs such as Common Justice and RESTORE have demonstrated that restorative justice programs founded on principles of victim-centeredness and offender accountability with a focus on rigor, repair, and community involvement are suited to all crimes, including those involving violence. Moreover, it is possible to implement a restorative justice alternative with the cooperation and support of prosecutors who recognize that restorative outcomes promote public safety and serve victims. RESTORE's partnership with a willing Pima County District Attorney's Office, and Common Justice's partnership with the King's County District Attorney's Office, which is now more than a decade-old, demonstrates that such partnerships are not only possible, but successful and durable. ${ }^{205}$

In sum, the failure of the traditional criminal justice system to serve many victims' needs and serve justice in sexual assault cases demands a new approach. As we have discussed, the vast majority of sexual assault cases go unreported and unprosecuted. Few result in convictions. Most sexual assault cases involve people who know each other. Most victimizers were victims themselves at one point. These data points suggest that a restorative, reparative approach holds more promise both for healing, in the case of victims, and reckoning, in the case of offenders. Sexual violence rips apart communities and the lives of individuals; left to fester-whether through neglect or through the incapacitation of the offender in a criminogenic environment that allows the victim no peace or safety-it infects future

$200 I d$. at 25.

201 Id. At 32.

202 Id. at 19.

203 Id. at 22.

204 Hopkins et al., supra note 153, at 300-01.

205 See, e.g., SERED, supra note 10, at 133; Koss, The RESTORE Program, supra note 21, at 10; Alexandra Brodsky, Can Restorative Justice Change the Way Schools Handle Sexual Assault?, THE NATION (Apr. 14, 2016), https:/www.thenation.com/article/archive/what-if-punishment-wasnt-theonly-way-to-handle-campus-sexual-assault/ (describing Koss and RESTORE's collaboration with prosecutors); Adam Wisnieski, Offender Meets Victim: A 'Survivor-Centered'Approach to Violent Crime, THE CRIME REPORT (Apr. 12,2017), https://thecrimereport.org/2017/04/12/offender-meetsvictim-a-survivor-centered-approach-to-violent-crime/ (describing Sered and Common Justice's collaboration with Eric Gonzalez, the Kings County District Attorney). 
generations. ${ }^{206}$ Ending this particular cycle of violence should be no different than ending the cycles of violence that lead to muggings, robberies, stabbings, and shootings. True respect, care, and advocacy for victims necessarily means offering them this alternative, which is centered on their needs and designed to empower them to have those needs met.

\section{CONCLUSION}

The victims' rights movement has altered the legal landscape. It has changed the way in which sexual assault crimes are charged, prosecuted, and punished. These reforms have been procedural and substantive. Victims have important procedural rights within the criminal process: to be kept up to date on the progression of their offenders' cases, to seek restitution, and to make a victim impact statement, among others. Victims of sexual assault in particular have seen important reforms. Rape victims are no longer required to prove that they actively resisted or sustained physical injury. A spousal relationship is no longer a defense to a rape charge. But despite these ground-shifting reforms, sexual assault prosecutions remain infrequent and largely unsuccessful. When cases are tried, victims may be frustrated or even re-traumatized; because they have no control, they cannot tell their stories their own way, their conduct is mischaracterized, their lives may be put under a microscope, and they have no right to assigned counsel to advise them and advocate for them in the process. Even the "best case" outcomes in which the offender is punished and receives a lengthy sentence provide little, if any, solace or healing.

Restorative justice may offer the best hope of vindicating victims' rights by providing them with what they need most: validation, acknowledgement, empowerment, reckoning, and accountability. The United States has been slow to embrace restorative justice in any context, and particularly in sexual assault cases, because we are wedded to the criminal process and criminal punishment, particularly when it comes to intimate acts of violence. We suggest that it is past time to rethink that approach. The criminal process is a failure for many victims, who are not healed, for many offenders, who are not deterred, and for society, which bears the cost of mass incarceration: the devastation of communities, the recidivism rates, and the ever-widening circle of harm as offending behavior, left unaddressed, is passed from one generation to the next. True victims' rights advocacy requires reckoning with these harsh realities and exploring a different approach — not as a replacement, but as an alternative. True victims' rights advocacy focuses on what victims themselves want rather than the embrace of tough-on-crime narratives that serve as little more than ill-kept or empty promises. What victims want may well be what restorative justice has to offer. It is time to give it more serious consideration.

206 Mills, supra note 5, at 482 ("A closer empirical look at victims reveals that, not only are victims likely to 'cross over' to become offenders, but that a vulnerability to and/or propensity for violence may be passed to subsequent generations.”). 